\title{
El Consejo Real de Castilla durante la minoría de Juan $\mathrm{II}^{1}$
}

\section{The Royal Council of Castile during the minority of John II}

\author{
Santiago GonZÁlez SÁNCHEZ \\ santitrifo@gmail.com
}

\begin{abstract}
RESUMEN
Trayectoria, funcionamiento y estructura del Consejo Real a lo largo de la minoría de Juan II. Desde los comienzos de esta etapa hasta mediados de 1420, el Consejo Real pasó por diferentes fases, esencialmente tres, y en todas ellas los encargados del gobierno del reino trataron de controlarlo, porque de su control se derivaba el de Castilla. Esto implicó, en ocasiones, el incremento del número de consejeros, sobre todo nobles y, en menor medida, eclesiásticos y letrados, lo que nos permite estudiar su composición: momentos de nombramiento, inclinación política y sus lugares de reunión.
\end{abstract}

Palabras clave: Consejo Real. Castilla. Poder. Política. Nobleza. Consejeros. Cortes. Juan II. Infante Don Fernando. Doña Catalina. Enrique III. Regentes. Ordenamiento. Siglo xv

\begin{abstract}
This article analyzes the development, function and structure of the Royal Council during the John II's minority. From the early years of this period until the mid-1420's, the Royal Council went through different phases, mainly three, during each of which the representatives of the kingdom's government tried to control the Council in order to control Castile itself. This situation meant, occasionally, an increase in the number of advisors, especially nobles, and, to a lesser extent, church authorities and university graduates, which facilitates this study of the Council's members: their moments of designation, political inclinations and meeting places.
\end{abstract}

Keywords: Royal Council. Castile. Power. Politics. Nobility. Advisors. Court. John II. Infante Don Fernando. Lady Katherine. Henry III. Regents. Legislation. 15th Century

Sumario: Introducción. 1. La reforma y atribuciones del Consejo Real. 2. El incremento del número de consejeros ¿reflejo del poder nobiliario? 3. El Consejo Real ¿limitador del poder de las Cortes? 4. La composición del Consejo Real y sus lugares de reunión. Conclusión.

\footnotetext{
${ }^{1}$ Este trabajo forma parte de mi Tesis doctoral titulada La Corona de Castilla: vida política (14061420). Acontecimientos, tendencias y estructuras, leída en la Universidad Complutense el 27 de mayo de 2010, y publicada en Internet en la Colección Digital de Tesis de la UCM (http://eprints.ucm.es). 


\section{INTRODUCCIÓN}

El interés por el estudio del Consejo Real podemos fecharlo en el siglo $\mathrm{XIX}^{2}$, aunque con anterioridad ya se había tratado de forma parcial o exclusiva ${ }^{3}$. Un estudio moderno sobre esta institución, además de completo y exhaustivo, es el de Salustiano de Dıs, ampliado con otros trabajos suyos que nos permiten tener una idea más exacta de su importancia en el gobierno de Castilla ${ }^{4}$. Este autor pone de manifiesto los orígenes bajomedievales del Consejo Real y descarta la idea de su precedente en la Curia Regia ${ }^{5}$, que mantienen otros ${ }^{6}$. Se hace eco de la polémica sobre la distinción entre gobierno y justicia, entre lo gubernativo y lo contencioso, que puede afectar al Consejo, respecto a lo cual señala, basándose en Gustavo Villapalos, que "el gobierno no era más que un aspecto de la justicia"? Y Y también se encarga de clarificar, por la confusión que ha provocado en algunos, la diferencia entre la vía de petición y la de merced $^{8}$. Estas consideraciones de Salustiano de Dios se hacen necesarias al comienzo de un trabajo que aunque no pretende entrar en aspectos de carácter teórico, ya tratados por este autor o por otros, intenta completar, en la medida de lo posible, lo que les falta a los estuDıos de éstos sobre el Consejo Real durante la minoría de Juan II de Castilla.

\section{LA REFORMA Y ATRIBUCIONES DEL CONSEJO REAL}

Al margen de los orígenes inmediatos, así como los avatares de esta institución durante la regencia de Enrique III, este monarca reorganizó el Consejo con las

${ }^{2}$ Luis María de la Torre de la Hoz Quintanilla y Vega (Conde de Torreánaz), Los Consejos del rey durante la Edad Media: su formación, autoridad y principales acuedos en Europa, y singularmente en Castilla, Madrid, 1884-1890, 2 vols.

${ }^{3}$ Rodrigo Méndez de SILVA, Catálogo real y genealógico de España, ascendencias y descendencias de nuestros Católicos Príncipes y Monarcas supremos. Reformado y añadido en esta última impresión con singulares noticias, curiosos orígenes de familias, Consejos, Ór denes, dignidades eclesiásticas..., Madrid, 1666. (Hay una edición publicada en Madrid en 1956); A. Martínez de Salazar y Canteras, Colección de memorias y noticias del gobierno general y político del Consejo: lo que se observa en el despacho de los negocios que le competían: $r$ egalias, preeminencias y autoridad de este supr emo tribunal, y las pertenecientes a la sala de señores Alcaldes, Madrid, 1764.

${ }^{4}$ Salustiano de Dios, El Consejo Real de Castilla (1385-1522), Madrid, 1982. Del mismo autor "Ordenanzas del Consejo real de Castilla (1385-1490)", Historia. Instituciones. Documentos, 7 (1980), pp. 269-320; Fuentes para el estudio del Consejo Real de Castilla Salamanca, 1986; "El ejercicio de la gracia regia en Castilla entre 1250 y 1530. Los inicios del Consejo de la Cámara", Anuario de Historia del Derecho Español, LIX (1990), pp. 323-352.

${ }^{5}$ Salustiano de Dios, El Consejo Real..., p. 69.

${ }^{6}$ Por ejemplo, Vicente Ángel Álvarez Palenzuela, "La Corona de Castilla en el siglo Xv. La Administración central”, Espacio, Tiempo y Forma. Serie III. Historia Medieval, 4 (1991), p. 90.

${ }^{7}$ Salustiano de Dios, El Consejo Real..., p. 339.

8 "toda reparación de agravios se pide por justicia, haya de resolverse por expediente o por proceso, puesto que siempre afecta a interés de parte, mientras que gracia o merced es algo que depende únicamente de la voluntad real y en principio su concesión no ocasiona perjuicio de partes". Salustiano de Dios, El Consejo Real..., p. 342. 
Ordenanzas promulgadas en Segovia el 15 de septiembre de $1406^{\circ}$ y en su testamento volvió a ocuparse de él al establecer el número de consejeros y la función que le correspondería a esta institución en el gobierno del reino ${ }^{10}$. Estas Ordenanzas tratan de convertir al Consejo en un órgano de gobierno y en la institución más importante "de la administración central"" miento del Consejo, al disponer el horario, las intervenciones, el lugar de celebración y su custodia, las cuestiones de carácter secreto, las comparecencias, la resolución de las discrepancias entre los consejeros, las atribuciones, etc ${ }^{12}$. Sin duda, Enrique III consideraba necesaria una puesta al día de la institución, sobre todo si se tiene en cuenta el papel que había desempeñado durante su minoría de edad. Para este monarca el Consejo tuvo una alta consideración, como lo probaría, por ejemplo la selección que hizo de consejeros ${ }^{13}$. Así, exponía al pontífice el inconveniente que se derivaba del nombramiento de un arzobispo de Toledo que no fuera castellano, pues su dignidad llevaba aneja su condición de miembro del Consejo Real ${ }^{14}$. Esta sería una razón, entre otras varias, que le hizo oponerse a la elección papal de Benedicto XIII en su sobrino y homónimo Pedro de Luna, aragonés.

Las atribuciones del Consejo Real eran muy amplias ${ }^{15}$. De acuerdo con su naturaleza se las ha agrupado en cuatro bloques: deliberativas, decisorias, ejecutivas y consultivas. $\mathrm{O}$ bien en tres, teniendo en cuenta si las competencias eran del monarca, del rey con el parecer del Consejo, o de este último sin tener que consultar al rey ${ }^{16}$.

9 Real Biblioteca de El Escorial. Mss. castellanos, Z II. 7, fols. 3b-8b, publicado por Francisco Martínez Marina, Teoría de las Cortes, vol. III, Madrid, 1979, nº XXIV, pp. 1292-1299 (1ª ed. Madrid, 1820); por Salustiano de Dios, “Ordenanzas...”, n V, pp. 281-286, y por el mismo en Fuentes..., n V, pp. 21-27.

10 Álvar García de Santa María, Le parti inedite della "Crónica de Juan II" di Álvar García DE SAnta María, Edizione critica, introduzione e note a cura di Donatella Ferro, Venezia, 1972, p. 30; Álvar García de Santa María, Crónica de Juan II de Castilla, Edición de Juan de Mata Carriazo y Arroquia, Madrid, 1982, pp. 34-35. En adelante, en las citas de esta última crónica no se indica el año de publicación.

${ }^{11}$ Benjamín GonzÁlez Alonso, Sobre el Estado y la Administración de la Corona de Castilla en el Antiguo Régimen. Las Comunidades de Castilla y otros estuDios, Madrid, 1981, p. 38.

${ }^{12}$ Francisco Martínez Marina, Teoría..., vol. III, n XXIV, pp. 1292-1299; Salustiano de Dios, “Ordenanzas...", n ${ }^{\circ}$ V, pp. 281-286 y en Fuentes..., n V, pp. 21-27.

13 "Ovo este rrey algunos notables onbres, rreligiosos y nobles, perlados y doctores, con quien se apartaua a ver sus fechos, y con cuyo consejo ordenava sus rreynos y justiçias. E lo que negar non se puede, alcançó discreçión para conosçer y elegir buenas paersonas para el su Consejo, lo qual non es pequeña virtud para el prínçipe". Lope de BARRIEnTos, Refundición de la Crónica del Halconero, Edición de Juan de Mata Carriazo y Arroquia, Madrid, 1946, p. 14.

14 Juan Francisco Rivera Recio, Los arzobispos de Toledo en la Baja Edad Media (S. XII-XV) , Toledo, 1969, pp. 99-100. Según Óscar Villarroel GonzÁlez, Las relaciones entre la Monarquía y el Arzobispado de Toledo en época de Juan II de Castilla (1406-1454), Toledo, 2002, p. 59, la presencia de los arzobispos de Toledo en el Consejo Real fue constante a lo largo del reinado de Juan II.

${ }^{15}$ Salustiano de Dios, El Consejo Real ..., p. 338, habla de las dificultades para hacer una clasificación de competencias del Consejo, para conocer sus atribuciones, debido a la diversidad de materias que trata.

16 Salustiano de Dios, El Consejo Real ..., pp. 81-82, 89. El mismo autor destaca que entre las atribuciones del Consejo Real, aunque fueran de carácter consultivo, estaban las de gracia, merced y 
De ahí que el Consejo tomase parte muy activa en los numerosos problemas que surgieron a lo largo de este período. Desde un punto de vista temático el Consejo se ocupó de cuestiones relacionadas con el gobierno -tanto en lo que se refiere a política interior como a exterior-, la guerra, la hacienda y la justicia.

\subsection{LA POLÍTICA INTERIOR}

El comienzo de la minoría de Juan II registra una gran actividad del Consejo Real así, por ejemplo, se le asigna un importante papel en la resolución del problema de la guardia del rey ${ }^{17}$. Las decisiones que tomó respecto al gobierno del reino, y estrechamente ligadas a la guerra con los granadinos, fueron acordar que la reina permaneciese en Castilla, mientras el infante estuviese en la campaña militar ${ }^{18}, y$, sobre todo, la división del reino en provincias que administraría cada uno de los dos regentes, en cumplimiento del testamento de Enrique III ${ }^{19}$, lo que comportaba la división de los órganos de gobierno, entre otros el Consejo Real ${ }^{20}$, y que se mantuvo hasta 1416, en que murió el rey de Aragón.

La separación física de los regentes no hizo más que ahondar las diferencias que les separaban, y en estas circunstancias, el Consejo, ideado como un mediador entre ellos $^{21}$, se convirtió en el lugar donde dirimir quién de los dos tenía el poder. Con la vuelta del infante don Fernando a la corte, después de la campaña militar de 1407,

patronato eclesiástico, que después serán propias de la Cámara de Castilla. Salustiano de Dios, Gracia, merced y patronazgo real. La Cámara de Castilla entre 1474 y 1530, Madrid, 1993, p. 89.

${ }_{17}$ Álvar García de Santa María, Le parti inedite..., p. 39, especialmente; Álvar García de Santa MARÍA, Crónica..., p. 44.

${ }^{18}$ Fernán PÉREz de GuzMán, Crónica del serenísimo príncipe don Juan, segundo rey deste nombre en Castilla y León, escrita por el noble y muy prudente caballer o Fernán PÉREZ DE GuZMÁn, Señor de Batres, del su Consejo, Biblioteca de Autores Españoles, Ordenada por don Cayetano Rosell, vol. LXVIII, t. II, Madrid, 1953, año 1, cap. XVIII, p. 283.

${ }_{19}^{19}$ B.N.P., Ms. 216, fols. 76r-84r, publicado por Michel GARCiA, "El historiador en su taller en Castilla, a principios del siglo XV. Edición y comentario del Ms Esp. 216 de la Bibliothèque Nationale de Paris", Atalaya. Revue Française d'Études Médiévales Hispaniques, 10 Automne (1999), nº 9, pp. 152163. Publicado con ligeras variantes como la fecha (1408 septiembre 28) y perteneciente al A.M.M., Cartulario Real 1391-1412, fols. 67r-70v en las obras de Juan Torres Fontes, "La regencia de Don Fernando de Antequera", Anuario de Estu Dios Medievales, 1 (1964), nº 1, pp. 420-428, y de María Victoria J. Vilaplana Gisbert, Documentos de la minoría de Juan II. La Regencia de Don Fernando de Antequera, CODOM, vol. XV, Murcia, 1993, nº XC, pp. 151-161; Fernán Pérez de GuZMÁn, Cróni$c a \ldots$, año 1, cap. XIX, pp. 284-286. Véase también de Juan Torres FonTes, "Dos divisiones políticoadministrativas en la minoría de Juan II de Castilla", Anales de la Universidad de Murcia, (1946-1947), pp. 339-353.

${ }^{20}$ B.N., Mss. 2507, Juan DÁvalos de Ayala, Vida y hechos ilustres... del gran condestable don Ruy López Dávalos el Bueno, Madrid, 1642, s/fol.

${ }^{21}$ Luis María de la Torre de la Hoz Quintanilla y Vega, Los Consejos..., p. 153, recuerda que una de las claúsulas del testamento de Enrique III disponía que los regentes no librasen nada que tuviese que ver con la tutela del rey y gobierno del reino sin que fuese avalado por la firma de dos consejeros. Luis SuÁrez Fernández, Nobleza y Monarquía. Puntos de vista sobre la Historia castellana del siglo $X V$, Valladolid, 1959, p. 76. Sobre la citada cláusula del testamento regio véanse Álvar GARCíA DE SANTA María, Le parti inedite..., pp. 34-35, y Álvar García de Santa María, Crónica..., pp. 39-40. 
quedó clara la necesidad de controlar el Consejo. La imagen que nos ha llegado es la de una oposición frontal en la que las trabas e impedimentos eran cotidianos, en la que se enmarca la salida apresurada de la corte de Juan Fernández de Velasco y de Diego López de Stúñiga, que puso al descubierto quién controlaba el Consejo que asistía a doña Catalina. La mediación posterior de los consejeros no consiguió solucionar las diferencias existentes entre ambos regentes ${ }^{22}$. A juicio del infante, que en esta ocasión es juez y parte, uno de los males que aquejaban a la corte era el de los "Consejos apartados de la reina"23. Es decir, que se habría pasado de los consejos paralelos a los consejos privados ${ }^{24}$. La decisión de don Fernando fue llegar a un acuerdo $^{25}$, en el que una de sus cláusulas vetaba la posibilidad de tener consejos apartados, habida cuenta los inconvenientes y disensiones que generaban, y otra que los consejeros de la reina tenían que quedar libres de cualquier juramento para que pudiesen expresar sus opiniones ${ }^{26}$. La vuelta atrás de la reina propició la reacción del infante, que expulsó de la corte a varios de los personajes más allegados a doña Catalina. El alcance de esta medida afectó al Consejo, a la Cancillería y a la cámara de la propia reina, con lo que el regente pasó a ejercer prácticamente todo el poder en solitario.

Uno de los problemas que requirió más atención del Consejo Real durante la minoría de Juan II fue la situación de desgobierno en algunas ciudades. Los dos ejemplos más paradigmáticos, aunque no los únicos ${ }^{27}$, y de los cuales nos han llegado más noticias son los de Sevilla y Murcia. En relación con la primera se plantearon dos problemas: la restitución de su forma de gobierno ${ }^{28} \mathrm{y}$ la inestabilidad banderiza,

${ }^{22}$ Fernán Pérez de Guzmán, Crónica ..., año 2, cap. XIV, p. 310.

${ }^{23}$ A.M.M., Cartulario Real 1391-1412, fols. 67r-70v, publicado por Juan Torres FonTes, "La regencia...”, no 1, pp. 420-428, y por María Victoria J. Vilaplana Gisbert, Documentos..., n ${ }^{\circ}$ XC, pp. 151-161; B.N.P., Ms. 216, fols. 76r-84r, publicado por Michel GarCia, "El historiador...", no 9, pp. $152-163$.

${ }^{24}$ La posible existencia de consejos privados por parte de los regentes es muy difícil de constatar, aunque en alguna ocasión lo encontremos así mencionado. Una de ellas, referida al final del asedio a Setenil, indica que el infante don Fernando convocó "a consejo privado a los que les son más fieles". Lorenzo Valla, Historia de Fernando de Aragón, Edición de Santiago López Moreda, Madrid, 2002, p. 99. En cualquier caso, la mayoría de las referencias, tanto cronísticas como documentales hablan de Consejo del rey o así se sobreentiende, aunque estuviera dividido.

${ }^{25}$ A.M.M., Actas Capitulares (1408 agosto 16), fol. 56r, contienen una "Carta y cuaderno de las conveniencias y posturas que se pusieron en razón del regimiento del reino entre el infante don Fernando y la reina doña Catalina por las provincias que cada uno debía regir", fechada el 19 de agosto de 1408. En la carta se mencionan las cosas que han pasado en el reino desde la muerte de Enrique III.

26 "La reina se negó porque ante la próxima marcha del infante deseaba estar asesorada por personas de su confianza, sobre todo teniendo en cuenta los fraudes que se habían detectado en los meses anteriores... ¿Acaso el infante le comunicaba a ella con quién se asesoraba o cómo lo hacía?” Ana EchEvArRía Arsuaga, Catalina de Lancaster, reina regente de Castilla (1372-1418), Hondarribia, 2002, p. 122.

${ }^{27}$ Se podría indicar también el caso de Guadalajara, a la que el rey se dirige y ordena a sus autoridades investigar y prender a "las malas personas e malfechores que ende biven o están, de qualquier condiçion que sean" y que los remitan al Consejo Real con los cargos que se les imputan. Francisco LaYna Serrano, Historia de Guadalajara y sus Mendozas durante los siglos XV y XVI, vol. I, Guadalajara, 1993, 2. ed., p. 190.

${ }^{28}$ Se produjo el 10 de abril de 1407, según da cuenta Álvar García de SAnTA María, Crónica..., pp. $84-85$. 
que fue el que más perduró ${ }^{29}$. En Sevilla, centro de los enfrentamientos, el concejo se dirigió al Consejo Real a finales del mes de agosto de 1414 dándole cuenta de la delicada situación por la que atravesaba ${ }^{30}$. Por lo que el monarca decretó el cumplimiento de una tregua a partir del 8 de octubre de 1414, facultando al doctor Fortún Velázquez que mandase comparecer ante los de su Consejo, puestos por su tío el rey de Aragón, a los que la incumpliesen ${ }^{31}$. Las reiteradas violaciones de los acuerdos establecidos llevaron a muchos caballeros, pertenecientes a los diferentes bandos, a prisión, de la que salieron bajo fianza acordada por el Consejo, tras la muerte de la reina $^{32}$. Posteriormente el Consejo se dirigió a Sevilla para que pagase el salario al alcalde de la justicia ${ }^{33}$, y uno de sus miembros, el doctor Juan Alfonso de Toro fue nombrado corregidor de la ciudad por seis meses ${ }^{34}$. Al margen de esto, Sevilla pleiteó ante el Consejo Real por distintos motivos, como por ejemplo con Pedro Ponce de León, señor de Marchena, sobre los términos de Alcalá de Guadaira que consideraba suyos $^{35}$.

El caso de Murcia fue más complejo, pues en él se manifiestan dos problemas: el enfrentamiento entre la monarquía y el concejo, que trata de defender las libertades municipales, y los intentos hegemónicos de la nobleza al frente del gobierno del municipio y su enfrentamiento en bandos nobiliarios. El gobierno de la ciudad de Murcia empeoró con la marcha del infante don Fernando como rey de Aragón. Muestra de ello fue el asesinato del bachiller en Leyes y alcalde real, Luis Gómez

${ }^{29}$ Un relato pormenorizado de los bandos sevillanos sobre todo a partir de 1416 lo ofrece Álvar García de Santa María, Le parti inedite..., pp. 187-207.

${ }^{30}$ A.M.S., Mayordomazgo XV, regesto en Francisco Collantes de Terán Delorme, Archivo Municipal de Sevilla. Inventario de los papeles del Mayordomazgo del siglo XV 1401-1416, vol. I, Sevilla, 1972, $\mathrm{n}^{\circ} 11$, p. 474.

${ }^{31}$ A.H.N., Sección Nobleza. Osuna, leg. 379, nº 47.

32 Fernán Pérez de Guzmán, Crónica ..., año 12, cap. II, p. 375.

33 A.M.S., Mayordomazgo XV, regesto en Francisco Collantes de Terán Delorme, Archivo Municipal..., vol. I, $\mathrm{n}^{\circ} 103$ y n $^{\circ} 109$, pp. 557 y 559 , respectivamente.

34 A.M.S., Mayordomazgo XV, regesto en Francisco Collantes de Terán Delorme, Archivo Municipal de Sevilla. Inventario de los papeles del Mayordomazgo del siglo XV 1417-1430, vol. II, Sevilla, 1980, nº 1, pp. 31-32. Diego Ortiz de ZúÑIGA, Anales eclesiásticos y seculares de la ciudad de Sevilla, Reproducción de la de 1795 con índices de José SÁnchez Herrero y otros, vol. II, Sevilla, 1988, p. 358, pone de manifiesto que se trató "por el Consejo Real (muerta la Reyna) de enviar nuevo corregidor... e enviaron al Doctor Juan Alonso de Toro". Sin especificar el tiempo véase Fernán Pérez DE GuzMÁn, Crónica ..., año 12, cap. V, p. 375. Agustín Bermúdez AzNAR, El Corregidor en Castilla durante la Baja Edad Media (1348-1474), Murcia, 1974, p. 119, señala que por el testamento de Enrique III se adscribía al Consejo la facultad de intervenir en el nombramiento de corregidores. Por su parte, Salustiano de Dios, El Consejo Real..., p. 346, indica que sobre el nombramiento de corregidores hay dudas de sí es un asunto sólo reservado al rey, o en el que el Consejo, según las Ordenanzas de 1406, debe consultar al monarca sobre la persona que debe elegirse. En lo que no parece haber duda es que, como se expone en el texto, durante la minoría de Juan II, hubo nombramientos de corregidores por los regentes o por el Consejo.

${ }^{35}$ Francisco Collantes de Terán Delorme, Archivo Municipal..., vol. I, no $32, \mathrm{n}^{\circ} 62$ y no 90 , pp. 504, 512 y 518, respectivamente. Sobre la situación jurídica de Alcalá de Guadaira y su dependencia de Sevilla véase Alfonso Franco Silva, El Concejo de Alcalá de Guadaira a fnes de la Edad Media (1426-1533), Sevilla, 1974, pp. 33-35, especialmente. 
de Salamanca, lo que motivó el envío como pesquisidor a la ciudad del licenciado Marcos Fernández ${ }^{36}$. A ello hay que sumar la competencia nobiliaria por el control político de la ciudad, que contribuyó a deteriorar más la situación. Por lo que entre 1413 y 1420 hubo dos sectores enfrentados sobre lo conveniente o lo improcedente de que hubiese un corregidor en la ciudad. Así, el concejo daba cuenta en la sesión de 8 de mayo de 1413 que algunas personas, vecinos y moradores de la ciudad, -creo que sería una facción del concejo- ${ }^{37}$ habían escrito a los señores del Consejo Real diciendo que en la ciudad de Murcia se producían muertes, robos y otros muchos maleficios, y que quienes los cometían se iban de la ciudad por falta de justicia ${ }^{38}$. Por ello, los miembros del Consejo querían proveer de corregidor a Murcia. El concejo señala la falsedad de estos hechos y decide enviar un representante ante el Consejo Real ${ }^{39}$ y dos hombres con cartas a don Fernando ${ }^{40}$. A mediados de mayo de 1413, el rey de Castilla, a iniciativa de su tío y regente, citaba a varios destacados personajes del concejo murciano para que comparecieran ante los de su Consejo ${ }^{41}$. Meses más tarde, la reina y el Consejo Real habían nombrado un corregidor para Murcia ${ }^{42}$. Año y medio después se habla del envío de un corregidor ${ }^{43}$ y el concejo de la ciudad manda a un representante ante el Consejo, alegando que la ciudad no lo quería y que iba en contra de la ordenanza regia el enviarlo donde lo pidiese la mayor parte ${ }^{44}$. Desde mediados de junio se señala que el Consejo había nombrado corregidor ${ }^{45}$, sin embargo, o no fue así o de otro modo la actitud del concejo es difícil de entender, ya que acordaron enviar un hombre con peticiones al rey y a los de su Consejo para que no nombrasen corregidor ${ }^{46}$. Dos días más tarde, en una sesión del concejo de Murcia, se dio a entender que el rey y los de su Consejo, que estaban por el rey de Aragón, habían nombrado corregidor para Murcia a Álvar Rodríguez de Escobar; siendo proveido por el rey de Aragón, mostrando sus preferencias de que antes viniese como corregidor el condestable Ruy López Dávalos ${ }^{47}$. Hay que esperar hasta 1418 para que se vuelva a dar una situación semejante. A finales de abril varios caballeros comparecían ante el Consejo Real pidiendo el envío de un corregidor para Murcia ${ }^{48}$.

${ }^{36}$ La orden en A.M.M., Cartulario Real 1391-1412, fol. 176r-v, publicado por María Victoria J. VIlaplana Gisbert, Documentos..., n ${ }^{\circ}$ CXCII, pp. 361-364. Entre los numerosos documentos que aluden a la muerte de Luis Gómez de Salamanca citamos A.M.M., Actas Capitulares (1413 octubre 6), fol. 69v.

${ }^{37}$ En ella se incluiría al pesquisidor, al que se le acusa después, como sabemos por A.M.M., Actas Capitulares (1413 junio 27), fols. 21v-22v.

38 A.M.M., Actas Capitulares (1413 mayo 8), fols. 118v-119r.

39 A.M.M., Actas Capitulares (1413 mayo 9), fol. 119v.

${ }^{40}$ A.M.M., Actas Capitulares (1413 junio 27), fols. 21v-22v.

${ }^{41}$ Eran Fernán Pérez Calvillo y Juan Ortega de Avilés. A.M.M., Cartulario Real 1411-1429, fol. $12 \mathrm{v}$, publicado por María Victoria J. Vilaplana Gisbert, Documentos..., ${ }^{\circ}$ CCXXII y CCXXIII, pp. 445-446 y 446-447, respectivamente. Ambos documentos están en el mismo folio.

${ }^{42}$ A.M.M., Actas Capitulares (1413 octubre 17), fol. 77r.

${ }_{43}$ A.M.M., Actas Capitulares (1415 mayo 13), fol. 10r-v.

${ }^{44}$ A.M.M., Actas Capitulares (1415 mayo 21), fol. 17r.

${ }^{45}$ A.M.M., Actas Capitulares (1415 junio 15), fol. 28v.

46 A.M.M., Actas Capitulares (1415 agosto 22), fol. 44r.

47 A.M.M., Actas Capitulares (1415 agosto 24), fol. 45r-v.

48 A.M.M., Actas Capitulares (1418 abril 28), fols. 90v-91r. 
La situación creada tras la muerte de la reina doña Catalina en junio, pudo colaborar en el nombramiento del condestable Dávalos como nuevo corregidor para la ciudad a comienzos de agosto ${ }^{49}$.

Existen numerosas referencias a las relaciones entre Murcia y el Consejo Real que sería prolijo detallar y que prueban el destacado papel del Consejo en el gobierno del reino ${ }^{50}$.

En efecto, la importancia del Consejo en el gobierno del reino motivó que las crisis políticas tuvieran su correspondiente traslación y lo afectaran. Así se puede ver en 1408 cuando, a la tradicional discrepancia entre la reina y el infante, se añaden las rivalidades nobiliarias entre los parciales de cada uno de ellos y el enfrentamiento por el restablecimiento del Consejo tal como lo había dispuesto Enrique III ${ }^{51}$, que provocaron el mal gobierno del reino ${ }^{52}$. La desaparición del regente supuso la reunificación del Consejo ${ }^{53}$ y la concentración del poder en manos de don Sancho de Rojas, arzobispo de Toledo, el almirante Alfonso Enríquez, el condestable Dávalos, Juan Fernández de Velasco, Diego López de Stúñiga y Pedro Manrique, adelantado de León ${ }^{54}$. Los problemas del Consejo en esos momentos fueron esencialmente dos. El primero es la usurpación de funciones por parte de un pequeño grupo formado alrededor de la reina ${ }^{55}$, y el segundo fue el malestar creado por el creciente protagonismo de don Sancho de Rojas, Juan Fernández de Velasco y Diego López de Stúñiga ${ }^{56}$. La muerte de la reina doña Catalina también implicó una remodelación del Consejo Real que, entre otras cosas, conllevó una mayor apertura en relación con los años anteriores, y una cierta relajación, al menos momentánea, de la línea política seguida en relación con los bandos de las ciudades ${ }^{57}$. Entre el óbito de la reina -2 de junio de 1418- y la entrega del regimiento a su hijo-7 de marzo de 1419- el Consejo desempeñó la función ejecutiva, al ocuparse del gobierno del reino ${ }^{58}$. Tras la mayoría de edad del rey, en 1419, la crisis del Consejo, que ya se venía arrastrando, se agravará. En ella pueden diferenciarse dos etapas, una primera cuya manifestación más clara fue la división del Consejo por tercios de año, y que acabó por desmantelar el sistema en el que el arzobispo de Toledo era la pieza clave. Y una segunda generada por las aspiraciones de los infantes de Aragón ${ }^{59}$, que arracaban desde la muerte de

${ }^{49}$ A.M.M., Cartulario Real 1411-1429, fol. 57r.

${ }^{50}$ Remito al lector interesado a consultarlas en mi Tesis doctoral.

${ }^{51}$ Álvar García de Santa María, Crónica..., pp. 245-247.

${ }^{52}$ Fernán Pérez de Guzmán, Crónica..., año 2, cap. XIV, p. 310.

${ }^{53}$ Doña Catalina lo convoca para darle cuenta de que asumía la tutela del rey y el regimiento del reino en solitario. Fernán Pérez de GuZMán, Crónica ..., año 10, cap. VIII, p. 371.

${ }^{54}$ Fernán Pérez de Guzmán, Crónica..., año 10, cap. X, p. 372.

${ }^{55}$ Fernán Pérez de Guzmán, Crónica..., año 10, cap. X, p. 372.

${ }^{56}$ Lope de Barrientos, Refundición..., p. 26; Fernán Pérez de Guzmán, Crónica..., año 10, cap. XII, p. 372.

${ }^{57}$ Fernán Pérez de Guzmán, Crónica ..., año 12, caps. I-II, pp. 374-375.

${ }^{58}$ Tras el fallecimiento de la reina, el monarca "con acuerdo de los de su consejo e de otros grandes de sus rregnos avía tomado en sy el rregimiento de los dichos sus rregnos". A.M.M., Actas Capitulares (1418 julio 14), fol. 24r.

59 Según Luis SuÁrez Fernández, Nobleza y Monarquía..., pp. 81-82, ellos convirtieron al Consejo Real en el órgano supremo de gobierno. 
doña Catalina y cuya manifestación más evidente fue la toma del poder por don Enrique. La situación del reino, seguramente exagerada por la defensa del Condestable Dávalos, años después, para tratar de justificar su actitud en Tordesillas, se presenta plagada de hechos en los que el Consejo, de ser ciertos, habría tenido mucho que ver: provisión de oficios a los parciales de los gobernantes, muchas dádivas, gastos desordenados, etc ${ }^{60}$. El Consejo volvió a quedar dividido, lo que unido a la influencia de algunos consejeros le restó autoridad ${ }^{61}$. El propio monarca ${ }^{62}$, aunque se desdijo más $\operatorname{tarde}^{63} \mathrm{y}$ la reina ${ }^{64}$ lo citan para justificar la acción de Tordesillas.

Se ha considerado que una de las razones de la decadencia de las Cortes fue la importancia que tuvo el Consejo para la Iglesia ${ }^{65}$ y para la nobleza. Sin embargo, las ciudades quedaron excluidas de él ${ }^{66}$, a pesar de la petición que plantean en las Cortes de Madrid de 141967. La ilegalidad del "golpe de Tordesillas" llevó al infante don Enrique a ofrecer a las ciudades representación en el Consejo, siendo una de sus primeras medidas de gobierno. En tal sentido se cursaron misivas a Carmona ${ }^{68}$, Ciu-

${ }^{60}$ A.M.C.Ro., leg. 4 , no 81, regesto en Ángel Barrios, José María Monsalvo Antón y Gregorio del Ser Quijano, Documentación medieval del Archivo Municipal Ciudad Rodrigo, Salamanca, 1988, n 92, pp. 157-159; B.N., Col. Burriel, Mss. 13236 y R.A.H., Salazar y Castro, N-5, fols. 1r-43r, publicado por Yolanda Guerrero Navarrete, Proceso y sentencia contra Ruy López Dávalos, Condestable de Castilla, Jaén, 1982, pp. 50-121.

${ }^{61}$ Luis María de la Torre de la Hoz Quintanilla y Vega, Los Consejos..., p. 152.

${ }^{62}$ A.G.S., Divs. de Castilla, leg. 11, no 3; A.M.C., Negociado General, leg. 81, nº 1; A.M.Ú., s/sig, publicado en Martín Jimena JuRAdo, Historia o anales del mvnicipio Albense Vrgavonense o villa de Arjona, Arjona, 1996, p. 404 (Facsímil de la publicada en Jaén en 1665); Fernando Ruano y Prieto, "El Condestable D. Ruy López Dávalos, primer Duque de Arjona", Revista de Archivos, Bibliotecas y Museos, $3^{\mathrm{a}}$ época, año VIII, XI julio-diciembre (1904), $\mathrm{n}^{\circ}$ IV, p. 408; Jonás CAstro Toledo, Colección diplomática de Tordesillas (909-1474), Valladolid, 1981, p. 254-255, $\mathrm{n}^{\circ} 442$; regesto en Manuel GonzÁlez JimÉnEz, "Documentos referentes a Andalucía en Nobleza de Andalucía de Gonzalo Argote de Molina”, Historia. Instituciones. Documentos, 17 (1990), nº 86, p. 99; y publicado por Miguel RuIz Prieto, Historia de Úbeda, Granada, 1999, p. 107 (Facsímil de la editada en Úbeda en 1906).

${ }^{63}$ A.H.N., Clero. Papeles. Tarragona, leg. 375, n 141, publicado por Áurea L. JAVIERRE Mur, "Relaciones diplomáticas entre Juan II de Castilla y Alfonso V de Aragón. (Documentos para su estudio)",

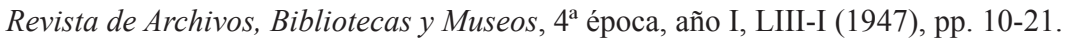

${ }^{64}$ A.M.M., Cartulario Real 1411-1429, fol. 106r.

${ }^{65} \mathrm{Al}$ respecto puede verse la obra de José Manuel NiETo Soria, Iglesia y génesis del Estado Moderno en Castilla (1369-1480), Madrid, 1993, pp. 154-164, especialmente.

${ }^{66}$ La sustitución de hombres buenos de los concejos por letrados, la mayoría doctores, tendría que ver con la sustitución progresiva del derecho de la tierra por el derecho civil, a juicio de Rafael GIBERT, El antiguo Consejo de Castilla, Madrid, 1964, p. 19.

${ }^{67}$ B.N., Mss. 1019, fol. 3v-4 y Mss. 13259, fol. 22v-23; R.A.H., Col. Salazar y Castro, K-3, fol. 3r-v. Cortes de los antiguos Reinos de León y Castilla vol. III, Madrid, 1866, (1419, pet. 18), pp. 20-21.

${ }^{68}$ A.M.Ca., leg. 26, publicado por José Hernández Díaz, Antonio Sancho Corbacho, y Francisco Collantes de Terán, Colección diplomática de Carmona, Sevilla, 1941, pp. 48-50; regesto por Manuel GonzÁlez Jiménez, Catálogo de la documentación medieval del archivo municipal de Carmona (12491474), vol. I, Sevilla, 1976, nº 193, p. 59. 
dad Rodrigo ${ }^{69}$, y a Murcia ${ }^{70}$, aunque no sabemos si enviaron sus representantes. Sin embargo, fueron las circunstancias las que les obligaron a ello, pues los mismos que se alzaron en Tordesillas manifestaban en 1419 que el rey "para bien regir hubiese consejo, así de los Grandes de su Reyno, como Perlados e Doctores" "11, sin mencionar a las ciudades para nada. Incluso el propio monarca tras el "golpe" expresaba su intención de guiarse por las disposiciones que su padre había dado en Segovia en $1406^{72}$, en las que no se aludía a esta cuestión. Con la posible inclusión de las ciudades en el Consejo, el infante y sus partidarios trataban de conseguir la adhesión a su causa, lo que hubiese incrementado el número de consejeros; problema heredado de la minoría ${ }^{73}$.

Conocemos pocos testimonios de las relaciones entre las ciudades y el Consejo, al margen de las reclamaciones de las primeras y de los mandatos del segundo. Sabemos, eso sí, que la ciudad enviaba comisionados ante el Consejo por asuntos que le incumbían ${ }^{74}$ y que, en ciertos momentos, se convertía en su informadora ${ }^{75}$. También que, a pesar del estricto reglamento, relacionado con la seguridad del lugar de celebración y de los consejeros, pudo existir algún caso de soborno a los porteros y ballesteros del rey que custodiaban al Consejo ${ }^{76}$.

Las cuestiones relacionadas con la Iglesia también fueron objeto de atención del Consejo Real. Al margen, al menos, de una provisión sobre los excomulgados ${ }^{77}$, el Consejo se ocupó sobre todo de la defensa de la jurisdicción regia sobre ciertas cuestiones eclesiásticas. En este sentido, nombró a un consejero, el doctor Juan Rodríguez, para que el obispo de Burgos, Pablo de Santa María, no se entrometiera en dar beneficios, visitar y dar licencias de sepulturas en las iglesias de la abadía de Covarrubias, puesto que le correspondía al rey como patrón ${ }^{78}$; y los regentes, tras consulta al Consejo, defendieron sus prerrogativas sobre el nombramiento de los conservadores de la Universidad de Salamanca, que se pretendía atribuir la Santa

${ }^{69}$ A.M.C.Ro., leg. 4, no 81, regesto en Ángel Barrios, José María Monsalvo AnTón y Gregorio del Ser Quijano, Documentación medieval..., no 92, pp. 157-159.

${ }^{70}$ A.M.M., Cartulario Real 1411-1429, fols. 103v-104r, publicado por Juan Abellán Pérez (ed.), Documentos de Juan II, CODOM, vol. XVI, Murcia-Cádiz, 1984, nº 34, pp. 78-79.

${ }^{71}$ Fernán Pérez de GuzMÁn, Crónica ..., año 13, cap. I, p. 377.

72 A.M.M., Cartulario Real 1411-1429, fol. 105r-v, publicado por Juan Abellán PÉrez (ed.), Documentos..., $\mathrm{n}^{\circ}$ 37, pp. 81-85. Las ordenanzas en Real Biblioteca de El Escorial. Mss, castellanos. Z II. 7, fols. 3b-8b, publicadas por Salustiano de Dios, “Ordenanzas...", $n^{\circ} \mathrm{V}$, pp. 281-286, y por el mismo en Fuentes..., n ${ }^{\circ}$ V, pp. 21-27.

${ }^{73}$ Fernán Pérez de GuzMán, Crónica ..., año 13, cap. IV, p. 378.

${ }^{74}$ El caso de Sevilla en Francisco Collantes de Terán Delorme, Archivo Municipal..., vol. I, no 99, p. 521.

${ }^{75}$ Por ejemplo, Sevilla al dar cuenta de la muerte del sultán granadino en 1408. Francisco Collantes de Terán Delorme, Archivo Municipal..., vol. I, no 209-XLII, p. 248.

${ }^{76}$ Francisco Collantes de Terán Delorme, Archivo Municipal..., vol. I, no 23, pp. 208-209.

77 Véase Toribio Minguella, Historia de la diócesis de Sigüenza y de sus obispos, vol. II, Madrid, $1912, \mathrm{n}^{\mathrm{O}} \mathrm{CL}$, pp. 625-628.

${ }^{78}$ A.C.Cov., leg. VIII, no 22, publicado por Luciano Serrano Pineda, Cartulario del Infantado de Covarrubias, en Fuentes para la Historia de Castilla por los PP. Benedictinos de Silos, vol. II, Valladolid, 1907, n CCLXIII, pp. 301-304. 
Sede ${ }^{79}$. También parece que intervino, de una u otra manera, en el conflicto suscitado por la posesión de la mitra de Plasencia entre don Gutierre Gómez de Toledo y don Gonzalo de Stúñiga, al encomendar el monarca a Pero Niño entrar en la ciudad para desposeer a este último ${ }^{80}$. Con una clara vertiente externa, aunque se trate preferentemente de una cuestión interna, estuvo el intento del infante don Enrique, amparado por el Consejo, de enviar al arcediano de Guadalajara ante Martín V, para legitimar el "Golpe de Tordesillas" y hacerse con la propiedad de las villas y lugares del Maestrazgo de Santiago ${ }^{81}$.

\subsection{LA POLÍTICA EXTERIOR}

Las relaciones con el reino granadino, incluyendo la guerra, fueron uno de los asuntos que directa o indirectamente ocupó a los consejeros castellanos buena parte de su tiempo. Poco después de la muerte de Enrique III y con anterioridad a la campaña militar de 1407 el Consejo y los regentes examinaron los agravios que los nobles denunciaban y dar satisfación a sus demandas ${ }^{82}$. La importancia del Consejo Real parece incrementarse después, pues recibe las denuncias de los abusos cometidos por las tropas en los pueblos de los alrededores de Sevilla, por la demora en el comienzo de la campaña de $1407^{83}$, participa en la elección del objetivo a atacar ${ }^{84}$, aconseja al infante las acciones previas ${ }^{85}$, le insta a abandonar el cerco a Setenil ${ }^{86}$, y deja oír su opinión sobre quiénes tenían que quedar como fronteros ${ }^{87}$.

${ }^{79}$ Citado por Luis María de la Torre de la Hoz Quintanilla y Vega, Los Consejos..., pp. 24-25 y 94-95. Publicado por Enrique Esperabé Arteaga, Historia pragmática e interna de la Universidad de Salamanca. I. La Universidad de Salamanca y los Reyes Salamanca, 1914, nº VII, pp. 92-94. Un breve regesto en Jesús Beltrán Llera, Gonzalo Gutiérrez Garrido, Jesús Martín Martín y Martín RodríGUEz Roso, Regesta de los documentos reales de la Universidad de Salamanca (1243-1833). Historia de la Universidad, Tomo VI-1, Salamanca, 1960, nº 45, p. 8. Sobre esa problemática véase María Isabel del VAl VALdivieso, "Universidad y luchas urbanas en la Castilla bajomedieval", Mayurqa. Homenatge a Álvaro Santamaría, vol. I, 22 (1989), p. 217.

${ }^{80}$ Gutierre Dítz de Games, El Victorial. Crónica de don Per o Niño Conde de Buelna, Edición y estudio Juan de Mata Carriazo, Madrid, 1940, pp. 314-315. No llegó a hacerse efectivo como señala José Manuel Nieto Soria, Un crimen en la corte. Caída y ascenso de Gutiere Álvarez de Toledo, Señor de Alba (1376-1446), Madrid, 2006, pp. 177-178.

${ }^{81}$ Álvar García de Santa María, Crónica de Don Juan II de Castilla, por el marqués de la Fuensanta del Valle D. José Sáncho Rayón y D. Francisco Zabalbúru, CoDoIn, vol. XCIX, Madrid, 1891, pp. 134-135; Fernán Pérez de GuZMÁn, Crónica ..., año 14, cap. XX, p. 388.

${ }^{82}$ Fernán Pérez de GuZmán, Crónica..., año 1, cap. XV, p. 282.

83 Álvar García de Santa María, Crónica..., p. 104.

${ }^{84}$ Fernán Pérez de Guzmán, Crónica ..., año 1, cap. XXXIV, p. 291; Álvar García de SAnta María, Crónica..., pp. 141-143.

${ }^{85}$ Biblioteca Zabálburu, Sección Altamira, carp. 10, $\mathrm{n}^{\mathrm{0}}$ 15, publicado por Luciano SerRano PINEDA, "Los señores de Baena y Cabra y Juan II", Boletín de la Real Academia de la Historia, LXXXVII (1925), n ${ }^{\circ}$ II, pp. 452-453.

${ }^{86}$ Fernán Pérez de Guzmán, Crónica..., año 1, cap. LI, p. 299; Álvar García de Santa María, Crónica..., pp. 176-178 y 180.

${ }^{87}$ Fernán Pérez de Guzmán, Crónica..., año 1, cap. LIII, p. 300; Álvar García de Santa María, Crónica..., p. 185. También da cuenta de este hecho Antonio Bohorques Villalón y Auñon, Anales 
Al año siguiente, -1408 - el cerco granadino a Alcaudete puso al descubierto las diferencias existentes entre el Consejo y el regente don Fernando, que cedió en sus pretensiones de hacer la guerra ${ }^{88}$. Como el mismo infante expresa en una misiva dirigida a Murcia el Consejo acordó hacer las paces -entiéndase treguas- con el reino nazarín 89.

En cualquier caso, no es la fortaleza de esta institución la que se estaba midiendo, sino la que a través de ella desarrollaban la reina y el infante, siendo la guerra con el reino de Granada un motivo más de enfrentamiento entre ambos regentes ${ }^{90}$. El dominio del Consejo, en ese contexto, se revelaba como fundamental para cortar las posibles aspiraciones de cualquiera de ellos. Su control por don Fernando a partir de 1408 hizo de este organismo un instrumento más dócil para su política.

Ya en 1410, y junto al regente, el Consejo convocó a los procuradores del reino a la ciudad de Córdoba, para que otorgasen el pedido y monedas necesarios ${ }^{91}$ para la nueva campaña ${ }^{92}$. En esa misma ciudad el Consejo participó en la elección de Antequera como objetivo militar ${ }^{93}$, y trató de impedir la marcha precipitada del infante hacia el frente ${ }^{94}$. Su actuación durante el cerco nos es prácticamente desconocida, sabemos, eso sí, que tras la batalla de la Boca del Asno, don Fernando, con su acuerdo y ante el requerimiento granadino, decidió enviar un embajador ante la corte nazarí. Un año después el Consejo tomó parte en la imposición de un pedido y monedas para proseguir la guerra contra el reino de Granada ${ }^{95}$. Sin embargo, con el establecimiento de treguas entre Granada y Castilla, se convirtió en garante de su cumplimiento, como ocurrió en 1413, cuando el rey, con su opinión dio la orden de que se investigara quiénes la habían quebrantado en Lorca y en Cartagena ${ }^{96}$. Ese mismo año, el pro-

de Morón, Transcripción del autógrafo (1633-1642), introducción, notas e índices de Joaquín Pascual Barea, Cádiz, 1994, cap. 11, p. 35.

${ }^{88}$ Fernán Pérez de Guzmán, Crónica..., año 2, caps. V y X, pp. 306 y 308, respectivamente. Álvar García de Santa María, Crónica..., pp. 220-221. El malestar del infante se refleja abiertamente en su conversación con los procuradores de las ciudades, como se puede ver en la página 233. La actitud del Consejo ¿coincide con la postura crítica que habían mantenido algunos nobles contrarios a proseguir la guerra?, o ¿se puede entender cómo una manifiestación de enfrentamiento con el infante y una mayor cercanía a doña Catalina?

${ }^{89}$ A.M.M., Actas Capitulares (1408 junio 27), fols. 24v-25r. Las treguas se comunicaron a los procuradores del reino reunidos en las Cortes de Guadalajara, como indica Álvar GARCía de SANTA MARÍA, Crónica..., pp. 229-232.

90 Álvar García de Santa María, Crónica..., pp. 236-237.

${ }^{91}$ Se les exigieron treinta y cinco millones. A.M.É., leg. IV, $n^{\circ} 148$, publicado por María Josefa Sanz Fuentes, Colección Diplomática del Concejo de Écija (1263-1474), Tesis doctoral inédita, Universidad de Sevilla, vol. III, Sevilla, 1976, nº 434, pp. 1486-1488.

${ }^{92}$ Francisco Collantes de Terán Delorme, Archivo Municipal..., vol. I, no 103, p. 305. El nombre de los procuradores que Sevilla envió para tratar con el Consejo del rey se encuentra en la misma obra, no 95, p. 303.

93 Fernán Pérez de Guzmán, Crónica..., año 4, cap. II, p. 316.

94 Álvar García de Santa María, Crónica..., p. 293.

95 A.M.Bu., Actas del Concejo, (1411 abril 6), fol. 16r-v.

${ }^{96}$ A.M.M., Cartulario Real 1411-1429, fol. 13r, publicado por Juan Torres FonTES, "La Regencia de Don Fernando el de Antequera y las relaciones castellano-granadinas. Cuarto período. Treguas", Miscelánea de Estu Dıos Árabes y Hebraicos, XXII fasc. 1 (1973), n XXI, pp. 55-56, también en La 
pio don Fernando, ya rey de Aragón, solicita del Consejo cumplimiento de justicia por una queja del rey de Granada, referida a la carga que habían tomado los del bajel del condestable de Castilla a uno de sus naturales ${ }^{97}$. En 1417 el Consejo Real y el de la reina decidieron otorgar treguas a los granadinos. La discusión no se centró como en anteriores ocasiones en si hacer guerra o conceder treguas, sino en si éstas serían de carácter anual, como hasta entonces, o bianual, como se concedieron ${ }^{98}$.

En relación con la guerra contra el reino de Granada y el ámbito fronterizo, el rey, de acuerdo con el Consejo, sin duda para atraerse la voluntad de las poblaciones fronteras murcianas y no disminuir su posible capacidad de combate, ordenó el cumplimiento de los privilegios que tenían concedidos desde tiempo atrás y que eran cuestionados, como la exención del pago de alcabalas en los botines de expediciones a tierras musulmanas ${ }^{99}$. Las competencias del Consejo Real se extendían mucho más, como se puede ver con la orden de proveer sobre la falta de pan y las pagas, que acumulaban un retraso de dos años en Alcalá la Real ${ }^{100}$, o con la entrega de la plaza de Tarifa al almirante Alfonso Enríquez ${ }^{101}$.

Por otra parte, el recurso a los dictámenes del Consejo, al menos en lo concerniente a las campañas militares frente al reino nazarí, dejaría a las claras la consideración que le merecía al regente, que trata de escudarse en él para eludir posibles responsabilidades por los errores que se pudieran cometer ${ }^{102}$.

En diversos momentos de estos años el Consejo Real trató cuestiones relacionadas con la Corona de Aragón, la más importante de ellas, sin duda, aunque tenga un vertiente interna, fue la decisión de avalar al infante don Fernando como candidato castellano al trono de Aragón ${ }^{103}$, y derivada de ésta la de enviar tropas en apoyo de

Regencia de Don Fernando el de Antequera y las relaciones castellano-granadinas (1407-1416), Cádiz, 1999, apéndice no 21, pp. 214-215, y por María Victoria J. Vilaplana Gisbert, Documentos..., n ${ }^{\circ}$ CCXXIV, pp. 447-448.

97 A.C.A., Cancillería, reg. 2383, fols. $28 \mathrm{v}-29$ r.

${ }_{98}$ Fernán Pérez de GuZmán, Crónica..., año 11, cap. II, p. 373.

99 A.M.M., Cartulario Real 1391-1412, fol. 53r, publicado por María de los Llanos MARTínez CARRILLO, "Rentas reales en los comienzos del siglo XV murciano. Arrendadores y recaudadores", Murgetana, 59 (1980), $\mathrm{n}^{\circ}$ 2, pp. 51-53, y por María Victoria J. Vilaplana Gisbert, Documentos..., $\mathrm{n}^{\circ}$ LXXIII, pp. 112-113.

${ }^{100}$ Publicados sin signatura por Carmen Juan Lovera, Colección diplomática medieval de Alcalá la Real. I. Transcripción de los documentos, Alcalá la Real, 1988, nº 62 y nº 63, pp. 92-94 y 94, respectivamente. También se encuentra un regesto del primer documento citado en la obra de la misma autora "Alcalá la Real, puerta a Granada de Castilla. Presentación de la Colección Diplomática Alcalaina", Boletín del Instituto de Estu Dıos Giennenses, año XXIII nº 91 (1977), n n 58, p. 42. En este artículo se encuentra el mandato del Consejo a los contadores mayores para que viesen esta petición librasen las pagas a la villa de Alcalá la Real, $\mathrm{n}^{\circ} 59$, p. 42.

101 A.D.A., carp. 2, $\mathrm{n}^{\mathrm{o}} 161 \mathrm{y} \mathrm{n}^{\mathrm{0}} 162$, para cuyo conocimiento remitimos a la obra de José Manuel Calderón Ortega, El Almirantazgo de Castilla: Historia de una institución con fictiva (1250-1560), Alcalá de Henares, 2003, nota 357, p. 79. R.A.H., Col. Salazar y CASTro, M-50, fols. 13r-22v.

102 "E porque si algún yerro se fiziese, por consejo de todos, que no se contase a él". Álvar García de Santa María, Crónica..., p. 143.

${ }^{103}$ Lope de Barrientos, Refundición..., p. 21; Fernán Pérez de Guzmán, Crónica..., año 5, caps. VIII-IX, p. 336; Luis PANZÁn, Recordanzas en tiempo del Papa Luna (1407-1435), Edición, prólogo y notas por Gregorio de Andrés, Madrid, 1987, pp. 58-62. 
sus partidarios en ese reino ${ }^{104}$, así como de prestarle apoyo jurídico en el derecho que decía poseer ${ }^{105}$. El matrimonio entre la infanta doña María y el infante don Alfonso de Aragón también fue asunto del que se ocupó el Consejo, en concreto el de la reina doña Catalina, ya que la dote asignada en principio a la infanta comportaba la entrega del marquesado de Villena, fronterizo con el reino de Aragón ${ }^{106}$. Las implicaciones geopolíticas que podía tener en el futuro hicieron que se cambiase por una dote en dinero. El pago posterior de la dote pudo ser también considerado por el Consejo, pues la reina doña María envió diversas cartas a personajes influyentes en la corte castellana, entre otros a algunos consejeros, en las que les daba cuenta de la ida del arcediano de Niebla para reclamar la satisfacción de uno de los pagos ${ }^{107}$. Sin embargo, ignoramos la razón última del envío de Álvaro de Luna por el Consejo ante la corte de Alfonso V de Aragón, pocos días después de la muerte de doña Catalina ${ }^{108}$.

En las relaciones con el reino de Navarra existe constancia de que el problema suscitado por huida de don Fadrique hacia ese reino motivó la convocatoria de un Consejo que decidió el envío de embajadores -Diego López de Stúñiga y a Diego Gómez de Sandoval- ante la corte de Pamplona. Este Consejo se reunió entre el 12 de marzo y antes del 5 de julio de 1411, por decisión del infante don Fernando, quien expuso la gravedad que representaba para Castilla la actitud del ex duque de Benavente ${ }^{109}$.

En relación con Portugal, el Consejo Real intentó poner fin a una etapa de hostilidades que, de manera más o menos esporádica, se prolongaba desde la década de los años ochenta del siglo anterior. Tras la muerte del rey don Enrique el Consejo Real envió embajadas para hablar de paz con los comisionados portugueses ${ }^{110}$. Sin embargo, las distintas posturas de los regentes, las elevadas pretensiones castellanas, la lentitud o interrupción de las negociaciones ${ }^{111}$, o problemas puntuales derivados de la vecindad, prolongaron una situación cada vez más difícil de sostener. En los primeros años de la minoría de Juan II el Consejo censuró la acción portuguesa de invadir ciertas aldeas ${ }^{112}$. Actitudes de este tipo también influirían en los debates que enfrentaron a sus miembros sobre la concesión de treguas o aceptar la demanda por-

104 Luis Panzán, Recordanzas..., pp. 64-65.

105 Alguno de los asistentes a Caspe, como fue el caso del doctor Pedro Sánchez del Castillo, era miembro del Consejo Real de Castilla. Jerónimo Zurita, Anales de la Corona de Aragón, Edición de Ángel Canellas López, vol. V, Zaragoza, 1980, 2a ed. Lib. XI, cap. LXXXIII, p. 251.

106 Fernán Pérez de Guzmán, Crónica..., año 9, cap. V, p. 363.

107 A.C.A., Cancillería, reg. 3108, fols. 108r, 108v-109r y 109r.

108 A.C.A., Cancillería. CR. Alfonso V, caja 7, nº 861.

109 Luis Panzán, Recordanzas..., pp. 57-58.

110 A.H.N., Sección Nobleza. Frías, caja 1, nº 30, regesto en María Teresa PeÑa Marazuela y Pilar León Tello, Archivo de los Duques de Frías. I Casa de Velasco, Madrid, 1955, n 2246, p. 372; publicado por Esther GonzÁlez CRESPo, Elevación de un linaje nobiliario castellano en la Baja Edad Media: los Velasco. Apéndice documental, Madrid, 1981, nº 34, pp. 131-134.

111 Sobre este aspecto A.G.S., Patronato Real, leg. 49, nº 14, publicado por Luis SuÁrez FERnÁNDEZ, Relaciones entre Portugal y Castilla en la época del infante don Enrique (1393-1460), Madrid, 1960, $\mathrm{n}^{\circ} 43$, pp. 172-175.

112 Álvar García de Santa María, Crónica..., pp. 276-277. 
tuguesa de una paz perpetua ${ }^{113}$. No hay que olvidar las preferencias de los consejeros por uno u otro de los dos regentes, que en esta cuestión parecían estar enfrentados ${ }^{114}$. Si el Consejo, de forma conjunta, dio su beneplácito a una implicación directa de la reina en las negociaciones con los portugueses ${ }^{115}$, tampoco se puede desvincular del apoyo explícito que habría pedido el infante en sus pretensiones al trono de Aragón, quizá se pueda hablar de una transacción. En estas circunstancias, los argumentos esgrimidos por el Consejo ${ }^{116}$ como la menor edad del rey, sus posibles derechos al trono portugués, las relaciones con el reino de Granada, las intenciones meriníes de querer pasar a la Península Ibérica o la pobreza del reino ${ }^{117}$, fueron importantes, pero otras razones de fondo obligaron a la firma de un acuerdo. La reina, en una misiva que envía a Juan I de Portugal pidiéndole diez o doce galeras para reemprender la guerra con los nazaríes en 1412, da cuenta de cómo tuvo que convencer a los del Consejo, entre otros, para alcanzar el acuerdo ${ }^{118}$.

Después del tratado de 1411 , y a pesar de ciertos problemas fronterizos ${ }^{119}$, los recelos hacia Portugal se debieron a sus preparativos de una armada. El Consejo Real, sin duda, tuvo conocimiento de toda la serie de bulos, quizá motivados, que circulaban sobre el objetivo de la flota portuguesa, entre los que se citaba a Sevilla. Por este motivo el Consejo ${ }^{120}$ se dividió sobre la postura a adoptar. Las posiciones han quedando personalizadas en el obispo de Ávila, don Juan de Guzmán, y en el adelantado de Cazorla, Alfonso Tenorio de Silva ${ }^{121}$. El primero aconsejaba tomar una postura defensiva, mientras que el adelantado de Cazorla sugería no hacer ningún

${ }^{113}$ Fernán Pérez de GuZmán, Crónica..., año 5, cap. V, p. 335.

114 Así, por ejemplo, se habla del "antiportuguesismo" de don Fernando, una muestra del cual puede verse en Álvar García de Santa María, Crónica..., p. 418.

115 A.M.Bu., Histórica, HI-177, regesto en Juan Antonio Bonachía Hernando y Julio Antonio Pardos Martínez, Catálogo documental del Archivo Municipal de Burgos: Sección Histórica (931-1515), vol. I, Burgos, 1983, n ${ }^{\circ}$ 464, p. 215. Publicado con la signatura: Actas Ayuntamiento de Burgos. 1411, fol. 30, por Luciano Serrano Pineda, Los conversos D. Pablo de Santa María y D. Alfonso de Cartagena. Obispos de Burgos, gobernantes, diplomáticos y escritor es, Madrid, 1942, no I, pp. 263-265. Y procedente del A.M.M., Cartulario Real 1391-1412, fols. 145v-146r, publicado por Luis SuÁrEZ FERnÁndeZ, Relaciones entre Portugal ..., n $\mathrm{n}^{\circ}$ 44, pp. 175-176, y por María Victoria J. Vilaplana GisBert, Documentos..., n ${ }^{\circ}$ CLV, pp. 302-304. También está publicado en Monumenta Henricina, vol. I, Coimbra, 1960, n 152, pp. 349-350. Referido a Murcia hay un regesto en R.A.H., 9/5432, Privilegios, Bulas, Donaciones, Conf rmaciones y otras Escrituras que se hallan originales en el Archivo y Tumbo de la Santas Yglesias de Murcia, Cartagena, Mula y Jumilla, t. XII, fols. 127v-131r.

${ }^{116}$ Las posturas que se señalan para este momento son las de la concesión de una tregua y la de una paz. Álvar García de Santa María, Crónica..., p. 418.

${ }^{117}$ R.A.H., Col. Salazar y Castro, M-13, fol. $173 \mathrm{v}$ y leg. 5, carp. $2, \mathrm{n}^{\mathrm{o}} 1$.

118 Fernão Lopes, Cronica del rei dom Joham de boa memoria e dos $r$ eis de Portugal..., Parte segunda, Lisboa, 1968, cap. CXCVII, pp. 437-441; Monumenta Henricina (1411-1421), vol. II, Coimbra, 1960, no 7, pp. 35-39.

119 A.C.A., Cancillería, reg. 2401, fols. 76v-77r y A.C.A., Cancillería. CR. Fernando I, caja 13, no 2549, este último publicado en Monumenta Henricina, vol. II, nº 38, pp. 97-100.

${ }^{120}$ Se habría reunido en Palencia y a él asistirían don Pablo de Santa María y su hijo Alfonso de Cartagena, ya miembro del Consejo, según indica Luciano Serrano Pineda, Los conversos..., p. 62.

${ }^{121}$ Me parece significativa la postura pactista de este personaje, cuya ascendencia era de un linaje portugués refugiado en Castilla. 
movimiento del que se dedujera recelo alguno por lo que hacían los portugueses. Su propuesta de enviar embajadores se aceptó, y cumplió el objetivo que buscaba: la firma del tratado por parte del rey de Portugal ${ }^{122}$, ya que los representantes portugueses no se habrían presentado en $1412^{123}$.

Con la mayoría de edad de Juan II, en 1419, se plantea otra vez la pretensión portuguesa de alcanzar una "paz perpetua", quizá temiendo represalias por el inicio de hostilidades entre Castilla e Inglaterra; de nuevo se manifiestan diversas opiniones en el Consejo, y se demora una solución definitiva con la determinación de enviar embajadores ante la corte portuguesa'24. Sin embargo, con el triunfo del "Golpe de Tordesillas" a mediados de julio de 1420, se puso en peligro el acuerdo que se había alcanzado un día antes ${ }^{125}$, y lo que es más grave el tratado establecido en 1411. En efecto, el Consejo se dividió sobre la actitud a adoptar, pero al contrario que en ocasiones anteriores, ahora la línea moderada no pudo imponerse en su seno. Al final, la imposibilidad de llevar a cabo una empresa militar contra Portugal acabó triunfando, pues la convocatoria a las ciudades no sirvió de nada; lo elevado de la operación ${ }^{126} \mathrm{y}$ la evolución política del reino pusieron fin a sus aspiraciones.

Los testimonios de la intervención expresa del Consejo Real en asuntos referidos a Francia y a Inglaterra son muy escasos y poco explícitos. La conclusión que se puede sacar de ellos es que las relaciones con estos dos reinos debieron de ocupar poco tiempo a los miembros del Consejo Real. Pero, podría ser errónea, pues existieron importantes intereses comunes. Con origen en el primer reino, aunque su procedencia fuera del "cónsul del rey e procurador delos sus súbditos e mercaderes deste reyno" llegaron varias cartas al concejo de la ciudad de Burgos, que envió alguna de ellas a los señores del Consejo ${ }^{127}$. Respecto a Francia, en 1418 llegaron embajadores de su rey solicitando ayuda militar contra el rey de Inglaterra, por lo que de acuerdo con las alianzas establecidas entre los dos reinos y las circunstancias que concurrían en el trono castellano se decidió convocar Cortes ${ }^{128}$. Procuradores y consejeros se re-

${ }^{122}$ El "Tratado de Outubro". Miguel Ángel OCHOA BRun, Historia de la diplomacia española , vol. I, Madrid, 1990, p. 252. Toda esta información procede de Gomes Eanes de ZurARA, Crónica da tomada de Ceuta, Introducción y notas de Reis Brasil, Mira-Sintra, 1992, cap. XXXI, pp. 120-124 y cap. XXXII, pp. 125-127, de quien lo recoge Monumenta Henricina, vol. II, no 39 y 40, pp. 100-103 y 103-106, respectivamente.

${ }^{123}$ A.M.M., Cartulario Real 1391-1412, fol. 177v, publicado por María Victoria J. ViLAPLAnA GisBERT, Documentos..., n CCV, pp. 391-392.

${ }^{124}$ Fernán Pérez de Guzmán, Crónica ..., año 13, caps. VIII y IX, p. 379. De aquí lo toma Monumenta Henricina, vol. II, n 158, pp. 318-319.

${ }^{125}$ A.H.N., Clero. Papeles. Tarragona, leg. 375, no 141, publicado por Áurea L. JAVIERRE Mur, "Relaciones diplomáticas...", pp. 10-21.

${ }^{126}$ Las fuentes consultadas discrepan a la hora de evaluar el coste de la operación de armar una flota y disponer de ocho mil lanzas y treinta mil peones. Fernán Pérez de GuzMÁn, Crónica..., año 14, cap. XXII, pp. 388-389 y Álvar García de Santa María, Crónica..., (1891), p. 139, la estiman en ciento veinte millones de maravedíes, mientras que según se expresa Juan II en A.H.N., Clero. Papeles. Tarragona, leg. 375, n 141, publicado por Áurea L. JAVIERRE Mur, "Relaciones diplomáticas...”, pp. 10-21, serían "setenta cuentos".

127 A.M.Bu., Actas del Concejo, (1411 abril 20), fol. 21v.

${ }^{128}$ Fernán Pérez de Guzmán, Crónica ..., año 12, cap. III, p. 375. 
unieron y decidieron repartir doce monedas en el reino para una armada que tendría que acudir en ayuda de Francia ${ }^{129}$ y contra Inglaterra ${ }^{130}$.

\subsection{LA HACIENDA}

El Consejo Real tuvo entre sus competencias en esta materia ver las apelaciones que se hacían de lo que librasen el alcalde o alcaldes de las aduanas ${ }^{131}$, determinar las diferencias entre los arrendadores y mercaderes sobre la cuantía a pagar de las rentas de los diezmos de la mar ${ }^{132}$, librar cartas sobre los derechos que tenían que satisfacer los mercaderes ${ }^{133}$, o mandar ejecutar los alcances que hacían los alcaldes mayores en los deudores de los concejos ${ }^{134}$. Al margen de ello, sus acuerdos en materia de hacienda diferenciaban entre contadores mayores y contadores de cuentas ${ }^{135}$.

Alguna de sus medidas, relativas al comercio interior, eran claramente proteccionistas y trataban de salvaguardar los intereses de la burguesía mercantil. Así ocurrió en Burgos, al impedir a los arrendadores poner guardas a puertas de la ciudad para solicitar a sus mercaderes que diesen cuenta de sus paños y mercancías ${ }^{136}$.

En relación con el ámbito fronterizo y el comercio exterior es probable que el Consejo tratase sobre el impuesto de la Quema, sobre lo que se le habría solicitado su opinión, aplazada para mejor ocasión, a la llegada a la corte de Castilla de una embajada procedente de Aragón ${ }^{137}$. También se sometió a su dictamen si se debían de satisfacer o no ciertos derechos, como la exea y corredura de los moros de ciertas villas

129 Fernán Pérez de GuzMán, Crónica..., año 12, cap. VIII, p. 376.

130 A.M.M., Cartulario Real 1411-1429, fol. 56, publicada por Juan Torres FonTEs, “Genoveses en Murcia (Siglo XV)", Miscelánea Medieval Murciana, II (1976), nº XI, pp. 138-140, y por María Victoria J. Vilaplana Gisbert, Documentos..., nº CCLXIII, pp. 534-535. Una carta procedente también del mismo archivo, aún inédita, trata sobre lo mismo y en términos muy parecidos. A.M.M., Cartulario Real 1411-1429, fol. 75r-v.

${ }^{131}$ Carta de Juan II a los obispados de las ciudades de Cuenca, Cartagena con el reino de Murcia y el arcedianazgo de Alcaraz. A.M.M., Cartulario Real 1411-1429, fols. 129r-130r.

132 A.G.S., E.M.R, Libro de Rentas de 1412 y 1447, publicado por Tomás González, Colección de cédulas, cartas-patentes, provisiones, reales órdenes y otros documentos concernientes a las Pr ovincias Vascongadas..., vol. I Condado y Señorío de Vizcaya, Madrid, 1829, nº 1, pp. 1-23. Transcrito en parte por Valentín SAInz DíAz, Notas históricas sobre la villa de San Vicente de la Barquera, Santander, 1986, pp. 122-123.

133 Francisco Collantes de Terán Delorme, Archivo Municipal..., vol. I, no 71, p. 488.

134 A.M.É., Docs. varios. n 55, publicado por María Josefa SAnz FuENTES, Colección Diplomática..., vol. III, $\mathrm{n}^{\circ} 453$ bis, pp. 1550-1553.

135 Luis María de la Torre de la Hoz Quintanilla y Vega, Los Consejos..., p. 119.

136 R.A.H., Col. Salazar y Castro, O-13, fols. 86v-87v. Se encuentra publicado en Colección de Cortes, Leyes, Fueros, Privilegios y otr os Documentos pertenecientes al gobierno de España, t. XI. Reynado de Juan II. Parte I desde 1407 a 1432, Carta real y privilegio de exención de puertas y aduanas a los vecinos de Burgos, fols. 2r-3r. Y en Antonio Siles, Colección Diplomática de España, t. IV, vol. VII, Años 1401-1433, fol. 47r-v, y citado por Luis de SALAZAR y CASTRO, Historia genealógica de la Casa de Lara, justif cada con instrumentos y escritor es de inviolable fe, vol. I, Madrid, 1696, Lib. V, cap. XII, p. 416.

137 Álvar García de Santa María, Crónica..., pp. 204-205. 
fronterizas con el reino de Granada, a un oficial del rey ${ }^{138}$. Además, en el Cuaderno de los diezmos y aduanas, y ante los incumplimientos de la saca de las cosas vedadas, se estipuló que lo que librasen el alcalde o alcaldes de dichas aduanas sería únicamente para los del Consejo del rey y para los contadores, y se encomendó a este organismo que dispusiese sobre las amenazas de algunos miembros de los estamentos privilegiados a los arrendadores reales, puesto que con ello se reducían sus rentas ${ }^{139}$.

El Consejo también fue el garante de que no se enajenara parte del tesoro regio. En caso de necesidad y si existía diferencia entre los regentes se debía seguir la opinión de la mayoría de sus integrantes ${ }^{140}$. Garantías que, en alguna ocasión, los procuradores de las ciudades también quisieron extender a las monedas otorgadas en Cortes ${ }^{141}$.

Otra competencia del Consejo Real, según las Ordenanzas de 1406, era enviar cartas de apremio a arrendadores, cogedores y fiadores, así como a cualquier deudor de las rentas reales ${ }^{142}$, o que impidiese su recaudación ${ }^{143}$. Con la firma del Consejo, el rey se dirige al tesorero mayor de Tierra de Vizcaya regulando la recaudación de los pechos y derechos de las anteiglesias de Vizcaya ${ }^{14}$. También lo hace a los arrendadores, directa o indirectamente, en varias ocasiones, para reclamar ${ }^{145}$, esclarecer las condiciones del arrendamiento y evitar conflictos con mercaderes ${ }^{146}$, o para impedir

${ }^{138}$ Eran Antequera, Cañete la Real, Zahara y Torre del Alhaquime. A.M.É., leg. IV, no ${ }^{\text {127 }}$, publicado por María Josefa SAnz Fuentes, Colección Diplomática..., vol. IV, no 474, pp. 1612-1615.

139 A.M.M., Cartulario Real 1411-1429, fols. 19v-27r, publicado por María Victoria J. ViLAPLana GisBert, Documentos..., n ${ }^{\circ}$ CCXLI, pp. 469-491. La última afirmación también se constata en Archivo Biblioteca del Seminario de Historia de las Instituciones de la Universidad Complutense de Madrid, s/ sig, publicado por Luis Garcia De Valdeavellano, "Un documento inédito de interés para la historia de la Hacienda castellana en la Baja Edad Media: el "Cuaderno de condiciones" fiscales de 1411", Moneda y Crédito. Homenaje a D. José Antonio Rubio Sacristán I, 128 (1974), pp. 42-58.

140 A.M.M., Cartulario Real 1391-1412, fols. 67r-70v, publicado por Juan Torres FonTEs, "La regencia...", (1964), no 1, pp. 420-428, y por María Victoria J. Vilaplana Gisbert, Documentos..., n ${ }^{\circ}$ XC, pp. 151-161; B.N.P., Ms. 216, fols. 76r-84r, publicado por Michel GARCIA, "El historiador...", n 9, pp. 152-163.

${ }^{141}$ B.N., 13104, fols. 49r-55v; R.A.H.; K-3, fols. 12r-17r; Colección de Cortes..., t. XI, fols. 101r113r. Publicados por Antonio Siles, Colección Diplomática ..., t. IV, vol. VII, fols. 241r-242v, y por Francisco Martínez Marina, Teoría..., vol. III, no XXV, pp. 1300-1308. Otro documento, procedente del Archivo Catedral de Córdoba, cuenta con un regesto en Antonio Garcia y Garcia, Francisco Cantelar Rodríguez y Manuel Nieto Cumplido, Catálogo de los manuscritos e incunables de la Catedral de Córdoba, Salamanca, 1976, nº 13, p. 131.

${ }^{142}$ Francisco Martínez Marina, Teoría..., vol. III, nº XXIV, pp. 1292-1299; Salustiano de Dios, “Ordenanzas...", nº V, pp. 281-286.

${ }^{143}$ Carta de Juan II con acuerdo del Consejo, desde Tordesillas, el 30 de julio de 1418, ordenado que nadie osase retener ni arrestar a los arrendadores ni a las rentas, aunque éstos tuviesen algunas deudas con él o con el concejo de Toledo, y amparándoles bajo su seguro. Así lo toma de A.C.To., V.4.A.1.30, Óscar Villarroel GonzÁlez, Las relaciones..., p. 146.

144 R.A.H., Col. Salazar y Castro, M-44, fols. 36r-43r.

${ }^{145}$ A.H.N., Sellos, leg. 28, no 1, regesto por Filemón Arribas Arranz, Sellos de placa de las cancillerías regias castellanas, Valladolid, 1941, p. 108.

146 A.G.S., E.M.R, Libro de Rentas de 1412 y 1447, publicado por Tomás GonzÁLEz, Colección de cédulas..., n 1, pp.1-23. Transcrito en parte por Valentín SaInz DíAz, Notas históricas..., pp. 122-123. 
que pidan el pago de la alcabala por los botines obtenidos en tierras granadinas ${ }^{147}$. Además, los consejeros tenían prohibido arrendar monedas, alcabalas y cualquier otra renta real, vetándoseles ser fiadores de los arrendadores ${ }^{148}$.

\subsection{LA JUSTICIA}

Con la toma del poder por Juan II se llevó a cabo una reordenación y división del Consejo. En relación con esto último, de las palabras de Pérez de GuzmáN ${ }^{149}$, algún autor ha deducido la posible existencia de un doble Consejo: "un órgano especializado dentro de otro más amplio". Un Consejo reducido, compuesto por un pequeño número de personas, cinco posiblemente, al que denomina Consejo secreto, que se ocuparían de despachar las cuestiones más complejas, así como las de gracia y merced; y otro Consejo, más amplio, el Consejo de la justicia, encargado de librar los asuntos de justicia y de gobierno, que tendrían que llevar la firma de varios consejeros ${ }^{150}$.

El Consejo habría preparado leyes ${ }^{151}$, pero además tenía competencias judiciales ${ }^{152}$, de las que había carecido en un principio ${ }^{153}$. Juan II, por medio de la pragmática de 23 de enero de 1410, facultó a los grandes oficiales de la corte, entre otros a los miembros del Consejo, el poder seguir sus pleitos ante él ${ }^{154}$. Fruto de esas competencias el Consejo Real entendió en los contenciosos que tenían los miembros de la media y alta nobleza del reino, que recurrieron a él para su resolución ${ }^{155}$. Así habría ocurrido con los hermanos Lobera, que pretendían querellarse ante el Consejo por la actitud belicosa del conde de Trastamara hacía ellos ${ }^{156}$. Sin embargo, el caso más

147 A.M.M., Cartulario Real 1391-1412, fol. 53r, publicado por María de los Llanos MARTínEz CARRILlo, “Rentas reales...", n² 2, pp. 51-53, y por María Victoria J. Vilaplana Gisbert, Documentos..., $\mathrm{n}^{\mathrm{o}}$ LXXIII, pp. 112-113.

${ }^{148}$ Luis Garcia De Valdeavellano, "Un documento inédito...", pp. 42-58.

149 "E luego fue tomado el juramento... y el Rey dixo... que luego se diese orden como algunos Caballeros del su Consejo con ciertos Doctores librasen las cosas de justicia; e otros negocios que fuesen de otra calidad, quería él ver con los que a él pareciese, para los determinar”. Fernán Pérez DE GuZMÁN, Crónica..., año 13, cap. IV, p. 378.

${ }^{150}$ Salustiano de Dios, El Consejo Real..., pp. 123-125.

${ }^{151}$ Salustiano de Dios, El Consejo Real..., p. 349, esta afirmación no la hemos visto corroborada en ningún caso en los años de nuestro estudio.

${ }^{152}$ Así lo reconoce el monarca en el momento que tomó el regimiento del reino, cuando manifiesta su deseo de que "se diese orden como algunos Caballeros del su Consejo con ciertos Doctores librasen las cosas de justicia. Fernán Pérez de GuZMÁn, Crónica ..., año 13, cap. IV, p. 378. Véase también José SÁnchez-Arcilla Bernal, La administración de justicia real en León y Castilla (1252-1504), Madrid, 1980, pp. 660-692.

${ }^{153}$ Salustiano de Dios, El Consejo Real..., p. 129.

${ }^{154}$ Existe un regesto realizado por Timoteo IgLesias Mantecón, Índice del Archivo Municipal de Cuenca, Cuenca, 1930, p. 133, y una reproducción del texto en el Libro de las Bulas y Pragmáticas de los Reyes Católicos, vol. I, Madrid, 1973, fol. 47r (Facsímil). Salustiano de Dios, El Consejo Real..., p. 129, también da cuenta de ello.

${ }^{155}$ Ya se ha visto como provee en relación con las querellas de los hijosdalgo al comienzo de la minoría de Juan II. Fernán Pérez de GuZmán, Crónica ..., año 1, cap. XV, p. 282.

${ }^{156}$ Procedente del Archivo Arzobispal de Santiago de Compostela, sin signatura, lo publica Antonio López Ferreiro, Historia de la Santa A. M. Iglesia de Santiago de Compostela, vol. VII, Santiago de 
importante en los años de nuestro estudio fue el de doña Leonor de la Vega. Esta señora, enfrentada con su hija Aldonza y con su yerno GarCia Fernández Manrique, por la posesión de Liébana, Pernía y Campo de Suso, obtuvo sentencia favorable a su demanda a finales de diciembre de $1408^{157}$. Sin embargo, doña Leonor ante su incumplimiento presentó una demanda de justicia, a comienzos de febrero de 1409, y como el contencioso persiste en los meses siguientes, a pesar del requerimiento de los regentes a su yerno ${ }^{158}$, y de las protestas de la señora de la Vega ${ }^{159}$, que seguramente compareció ante el infante y varios miembros del Consejo por esta razón en septiembre de $1409^{160}$, Juan II determinó que el Consejo no podía cometer ejecución, tenía que enviarla a las justicias ordinarias, salvo en el caso de que ésta fuera negligente ${ }^{161}$.

Por otro lado, y en un ámbito que podemos denominar hacendístico-judicial se enmarcan los mandamientos del Consejo ordenando la reasignación de ciertas ren$\operatorname{tas}^{162}$, entendiendo en pleitos sobre la propiedad de alguna de ellas ${ }^{163}$, u obligando a algún concejo a pagar el salario de los alcaldes ${ }^{164}$. En ocasiones, recibía notificación de alguna ciudad dándole cuenta de las razones por las que habían establecido cierto impuesto, como ocurrió con Sevilla, a finales de noviembre de $1406^{165}$.

Con la división del Consejo tras la marcha de don Fernando a Aragón las ciudades bajo su administración, debían dirigirse a los de su Consejo, que estaban en Castilla, para plantear una querella o hacer una petición ${ }^{166}$.

Compostela, 1983, apéndice n ${ }^{\circ}$ VII, pp. 30-32 (Facsímil de la de Santiago de Compostela, 1904).

157 A.H.N., Sección Nobleza. Osuna, leg. 1810, nº 10, publicado por Rogelio Pérez Bustamante y GonZÁlez dE LA VEGA, "El proceso de consolidación de un dominio solariego en la Castilla Bajomedieval. El Señorío de la Vega, 1367-1432”, Altamira, XL (1976-1977), apéndice documental X, p. 139.

158 A.H.N., Sección Nobleza. Osuna, Becerro, no 78, fol.77r-v; B.N. Mss. 18695, nº 30, publicado por Rogelio Pérez Bustamante y González de la Vega, "El proceso...", apéndice documental VIII, pp. 135-137; regesto en Rogelio Pérez Bustamante y González de la Vega y José Manuel Calderón Ortega, El Marqués de Santillana. Biografia y documentación, Santillana del Mar, 1983, p. 151, nº 31.

159 R.A.H., Col. Salazar y Castro, M-23, fols. 149r-150r.

160 R.A.H., Col. Salazar y Castro, M-10, fol. 123r, regesto en Javier Ortiz Real, Fuentes documentales para la historia de Torrelavega. Archivos Nacionales, Santander, 1995, n² 250, p. 88.

${ }^{161}$ De las leyes de Recopilacion que contiene los libros primero, segundo, tercero, quarto i quinto, Tomo I, Madrid, MDCCLXXV, Lib. IV, tít. XXI, 1. 15, p. 628.

${ }^{162}$ Como consecuencia de la destrucción de la aljama de los judíos se mandó a los contadores que la cantidad que tenía el cabildo situada en la cabeza de pecho de los judíos se les pusiese en la renta del almojarifazgo de Córdoba. A.C.Có., 028 cajón L, nº 314.

163 A.C.Có., 028 cajón Z, nº 48, 55 y 62.

${ }^{164}$ Francisco Collantes de Terán Delorme, Archivo Municipal..., vol. I, no 103 y 109, pp. 557 y 559, respectivamente; A.S.Cl.T., caja 2, expte. 19, regesto en Jonás CASTRo Toledo, Colección diplomática de Tordesillas (909-1474), Valladolid, 1981, nº 398, pp. 232-233.

${ }^{165}$ Estableció el pago de un cornado por libra de carne, por la necesidad de dinero para sufragar los gastos de las guardas, escuchas y atalayas que tenía puestas contra tierra de moros. Francisco Collantes de Terán Delorme, Archivo Municipal..., vol. I, no 208, p. 192.

166 A.V.M., -S 2-158-20, publicado por Agustín Millares CArlo, Documentos del Archivo General Villa Madrid, vol. II, Madrid, 1943, Segunda Serie, $n^{\circ}$ V, pp. 17-20; regesto en María del Carmen CAYEtano Martín, La documentación medieval en elArchivo de Villa (1152-1474), Madrid, 1991, pp. 79-80. 
El Consejo se relaciona con las ciudades a través de cartas de mandamiento, debiendo comparecer ante él si incumplían sus órdenes ${ }^{167}$, les pide el envío de ciertas personas ${ }^{168}$, provee sobre cuestiones relacionadas con el regimiento ${ }^{169}$, o les requiere cierta cantidad de provisiones para su mantenimiento ${ }^{170}$. Esta intensa comunicación entre el Consejo y las ciudades, unida a la existente entre el Consejo y los corregidores y jueces de residencia, durante el desempeño de sus oficios, se ha considerado una muestra de intervencionismo en la vida de los municipios ${ }^{171}$. Con la unificación del Consejo Real, tras la mayoría de edad del monarca, las ciudades y villas vuelven a dirigirse a él para solventar los pleitos que mantenían ${ }^{172}$.

El Consejo también proveyó en lo dispuesto sobre las minorías, y en tal sentido suspendió los ordenamientos de Enrique III sobre judíos y musulmanes ${ }^{173}$.

\section{EL INCREMENTO DEL NÚMERO DE CONSEJEROS. EL PREDOMINIO DE LA NOBLEZA}

Los tres grupos que integraban el Consejo Real: nobles, eclesiásticos y letrados, debían ser similares, un tercio del total de dieciséis, aunque la realidad no fue así. El asiento en el Consejo de los hijos del infante don Fernando, que Enrique III reconocía en su testamento, desequilibraba la correlación de fuerzas. Además, durante la minoría de Juan II el aumento en el número de consejeros se debió también a la duplicidad que hubo de consejos, hasta 1416. Por lo tanto, los consejeros, al ser cargos vitalicios, pasaron después a integrarse en uno solo. De ahí que el rey, al alcanzar la mayoría de edad, reconociese que la reina y el infante don Fernando "en tiempo de sus tutorías habían acrecentado muchos Caballeros e Letrados en su Consejo, allende los que el Rey Don Enrique... habia dexado" ${ }^{174}$. La desproporción de nobles también se constata en la división cuatrimestral del Consejo, pues de los trece consejeros

${ }^{167}$ A.M.É., leg. 18, $n^{\circ} 1$. Procedente de este mismo archivo y con la signatura carp. II, $n^{\circ}$ 53, está publicado por María Josefa SAnz Fuentes, Colección Diplomática ..., vol. IV, pp. 1557-1559.

168 A.V.M., -S 2-44-14, publicado por Agustín Millares Carlo, Documentos..., vol. II, n ${ }^{\circ}$ XII, pp. 39-40; regesto en María del Carmen Cayetano Martín, La documentación..., p. 82.

${ }^{169}$ Por ejemplo, en el caso de Madrid, mandándoles tener labradores y pecheros en el concejo, cada vez que se hiciese un repartimiento. A.V.M., -S 2-347-12, S 2-447-12, publicados por Agustín MiLLARES Carlo, Documentos..., vol. II, $n^{\circ}$ XVI, XVII, pp. 53-55 y 57-62, respectivamente; regesto en María del Carmen Cayetano Martín, La documentación..., p. 85.

170 A.V.M., -S 2-91-9, S 2-44-14, S 2-91-14, S 2-91-13, S 2-91-15, publicados por Agustín MIllares Carlo, Documentos..., vol. II, no VI, VIII, IX, X, XIII, pp. 21-23, 29-30, 31-32, 33-34, 41-43, respectivamente; regesto en María del Carmen Cayetano Martín, La documentación..., pp. 80, 81, 82,81 y 83 .

${ }_{171}$ Salustiano de Dios, El Consejo Real..., p. 384.

${ }^{172}$ Así ocurrió con Espinosa de los Monteros, cuyos procuradores se habían querellado ante el rey y los de su Consejo por los agravios que habían recibido por Juan Fernández de Velasco y sus merinos, oficiales, escuderos, vasallos y paniaguados. A.H.N., Sección Nobleza. Frías, caja 235, nº 35.

173 A.M.M., Actas Capitulares (1418 septiembre 24), fol. 69, publicado por Juan Torres FonTes, "Los judíos murcianos en el reinado de Juan II", Murgetana, 24 (1965), n I, pp. 28-29.

${ }^{174}$ Fernán Pérez de GuZmán, Crónica ..., año 13, cap. IV, p. 378. 
citados, diez son nobles y tres eclesiásticos ${ }^{175}$. Además, el monopolio de la nobleza tampoco se puede desvincular de su presencia en la corte, por ejercer cargos en ella, por sus vínculos de parentesco, u otras razones ${ }^{176}$.

En el proceso de predominio de la nobleza hubo varios momentos clave, aunque no en todos los casos se correspondería con un incremento en el número de consejeros. Uno fue, sin duda, el golpe de 1408, cuando don Fernando se hizo con las riendas del poder y dió de lado a la reina. Al margen de razones coyunturales, como las relacionadas con las hostilidades contra el reino granadino, se encontraban otras de índole estructural, como la formación del Consejo y su influencia. De ahí que este organismo se convierta en el principal objetivo del infante y que en adelante le sea claramente favorable, más todavía con la vuelta a la corte de Diego López de Stúñiga y de Juan Fernández de Velasco que, según algún autor, "sin vacilar, votaron cuantas decisiones presentó el infante" 17 . Otro se produjo en 1416, tras la muerte del rey de Aragón, cuando la reina asumió la regencia en solitario y acabaron haciéndose con el control del gobierno del reino Diego López de Stúñiga, Juan Fernández de Velasco y Sancho de Rojas, arzobispo de Toledo. En estas circunstancias es probable que no se produjera un aumento del número de consejeros, aunque no sea más que por el estrecho control que los citados tenían de las riendas del poder. La tercera fecha a tener en consideración es la de la muerte de doña Catalina en 1418. Tras la cual se dispone que, en adelante, los que habían formado parte del Consejo de Enrique III estuviesen en la corte, para regir el reino, junto al maestre de Santiago, el almirante, el condestable, el adelantado de León, el mayordomo mayor del infante don Enrique y, además, se tratará de apartar de las tareas de gobierno a Juan Fernández de Velasco y al arzobispo de Toledo ${ }^{178}$. A partir de entonces, se empiezan a configurar los dos bloques que se agruparán alrededor de los infantes de Aragón y que culminarán con la división del Consejo por tercios de año. Esta medida supuso un nuevo giro en relación con el Consejo Real, y por consiguiente con el gobierno del reino. Aproximadamente tres cuartas partes del total del Consejo las tienen los nobles y el cuarto restante los eclesiásticos. El momento final de este ascenso lo marca el ejercicio del poder por parte del infante don Enrique, es decir entre mediados de julio y comienzos de diciembre de 1420. Durante este período el infante y los de su opinión utilizaron el nombramiento de consejeros para atraerse partidarios, sobre todo entre los más importantes, logrando que el monarca hiciese de su Consejo a cerca de treinta personas ${ }^{179}$.

175 Fernán Pérez de Guzmán, Crónica ..., año 13, cap. X, p. 379.

176 Sin referirse en concreto a esta época, Jesús D. Rodríguez de Velasco, El debate sobre la caballería en el siglo XV. La tratadística caballer esca castellana en su mar co europeo, Salamanca, 1996, p. 62, llama la atención sobre la lucha por la primacía entre caballeros y letrados en el Consejo, ante lo cual los nobles buscaron perpetuar su unión con el monarca a mediante la caballería, aunque no sería el único procedimiento.

177 Lope Pascual Martínez, "La Cancillería real castellana durante la regencia del infante don Fernando de Antequera", Miscelánea Medieval Murciana, XI (1984), p. 185.

${ }^{178}$ Fernán Pérez de GuZmán, Crónica ..., año 12, cap. I, pp. 374-375.

179 Álvar García de Santa María, Crónica..., (1891), p. 124. Esto contradice en parte la afirmación de Luis María de la Torre de la Hoz Quintanilla y Vega, Los Consejos..., p. 159, que considera que con la división del Consejo por tercios de año se debilitaba el prestigio de formar parte de él. 
Por otra parte, el dominio de la nobleza en el Consejo no es más que la constatación del que ejercía sobre la sociedad en general. El prestigio social de que gozaban y que podían prestar con su presencia a una institución les proporcionaba un ascendiente que no tenían los letrados o los procuradores de las ciudades. La importancia cada vez mayor de la nobleza en el Consejo ¿no sería también consecuencia del creciente papel de las actividades bélicas durante estos años de la minoría? En efecto, creemos que puede ser un factor a tener en cuenta y que la pertenencia al Consejo, además de una especie de merced por sus actuaciones, se deba a su experiencia en este campo ${ }^{180}$. Sin embargo, sabemos que los regentes se vieron obligados a formar un grupo de fieles con los que compartir las tareas de gobierno, recompensar fidelidades, o atraerse a los descontentos con el otro. En ese sentido se habría producido una especie de rivalidad entre ellos que provocó el incremento en el número de oficiales ${ }^{181}$, y que quizá pueda hacerse extensivo a los consejeros. Poco después el infante don Enrique, maestre de Santiago, llevó a cabo la misma política ${ }^{182}$. El cargo de consejero real también podía servir para resarcir o recompensar al noble, bien es verdad que sólo lo son los más importantes de entre ellos. La monarquía, ante la falta de territorios de realengo para repartirles, optó por concederles esta merced. De su cercanía al monarca se derivaban poder y riqueza ${ }^{183}$, como las que les proporcionaban los elevados emolumentos que percibían ${ }^{184}$.En este acceso al Consejo Real hay también una especie de autorregulación por parte de la propia nobleza, que no consentirá que ninguno de sus miembros ocupe una posición predominante. Esto se puede ver durante los años de la minoría de Juan II en la hegemonía de Diego López de Stúñiga, Juan Fernández de Velasco y Sancho de Rojas, tras la muerte del rey de Aragón; en la que ejerció don Sancho de Rojas sólo o acompañado por Juan Hurtado de Mendoza, o en la que trató de imponer el infante don Enrique. En todos los casos, con mayor o menor rapidez se tratará de restablecer un equilibrio entre los miembros del grupo.

${ }^{180}$ Refiriéndose a la elección de Setenil sobre Ronda en 1407 se indica que el infante se dejó aconsejar por el Consejo, entre otras razones, “por que ellos avían visto más de guerra que él”. Álvar GARCíA de Santa María, Crónica..., p. 143.

181 E si ofiçio vacaua alguno, e era dado por parte del Infante e del Cosejo del Rey, luego le hera contradicho e dado por la otra parte a otro”. Álvar García de SANTA María, Crónica..., p. 237.

182 Sin especificar ningún nombre Álvar García de Santa María, Crónica, (1891), p. 124. El caso más evidente fue el de don Álvaro de Luna, nombrado consejero. Fernán PÉrez DE GuzMÁn, Crónica..., año 14, cap. III, p. 381.

183 Rafael Gibert, El antiguo Consejo..., p. 20, refiriéndose a la concesión del cargo de consejero años más tarde dice que se concedía como beneficio y como honor.

184 A Per Afán de Ribera y al conde don Enrique Manuel se les asignó en 1409 la cantidad de sesenta mil maravedíes. Biblioteca Colombina. Infanta. 3-7-5, publicado por María Asunción VILAPLANA, "Un ajuste de cuentas del alcabalero mayor de Sevilla Pedro Ortiz (1420)", Historia. Instituciones. Documentos, I (1974), pp. 473 y 474, respectivamente. Sin fecha concreta, al almirante Enríquez se le asigna la cantidad de noventa mil maravedíes, según Pascual Martínez SopenA, El estado señorial de Medina de Ríoseco bajo el almirante Alfonso Enríquez (1389-1430), Valladolid, 1977, p. 159. Sin embargo, conocemos que en 1420 los consejeros percibirían cien mil maravedíes, como se señala en el caso del don Álvaro de Luna y otros "Caballeros" a los que no se nombra. Álvar García de Santa María, Crónica..., (1891), p. 94; Fernán Pérez de Guzmán, Crónica..., año 14, cap. III, p. 381. 


\section{EL CONSEJO REAL ¿LIMITADOR DEL PODER DE LAS CORTES?}

Consejeros y procuradores de las ciudades se reunieron en las Cortes de Toledo de 1406, donde se trató sobre la cantidad que el reino tendría que pagar para la guerra contra los nazaríes ${ }^{185}$. Es muy probable, como ocurriría años más tarde, que el Consejo actuase como moderador de dos posturas muy distantes entre sí, que en este caso eran las que mantenían el monarca y los procuradores. La colaboración entre los miembros de las dos instituciones no se circunscribía propiamente a las reuniones de Cortes. En alguna ocasión, consejeros y procuradores participaron con los regentes y decidieron la política a seguir ${ }^{186}$. En otros momentos, más que hablar de colaboración, a veces forzada por las circunstancias, cabe hablar de oposición, y así el Consejo tuvo que actuar, sino a requerimiento de las Cortes, sí impelido por éstas ${ }^{187}$. En otra ocasión son las Cortes las que tendrán la última palabra ante las discrepancias existentes en el Consejo ${ }^{188}$.

Por otro lado, el Consejo se encargó de convocar Cortes cuando faltaron los regentes, como ocurrió en 1418 y en 1419. Sin embargo, lo más destacable fue la participación de algunos de los consejeros regios en alguna de estas asambleas, aunque no en calidad de procuradores. En este sentido, tenemos constancia de que fue así en las de 1419, con el parlamento del arzobispo de Toledo y con las palabras que dirigió el almirante, en nombre de los grandes y de los procuradores de las ciudades ${ }^{189}$. O en las de 1420, en Ávila, con la alocución de don Gutierre Gómez de Toledo, arcediano de Guadalajara ${ }^{190}$. En ambos casos, las palabras de los dos prelados del Consejo tratan de encauzar la opinión de los procuradores en Cortes en una determinada dirección política, que puede considerarse la oficial o predominante en esos momentos, como se ve con toda claridad en las Cortes reunidas en Ávila.

El Consejo también recibió el encargo de negociar, por parte del monarca, con los procuradores en las Cortes de 1418, para armar una flota que fuese contra Inglaterra y en ayuda del rey de Francia. Su labor fue un éxito, pero los procuradores exigieron al rey y a su Consejo jurar que lo acordado en ayuda de Francia no tuviera más que ese destino ${ }^{191}$.

Por otro lado, hay que tener en cuenta que los miembros y funciones del Consejo Real propiciaban un cierto alejamiento de las pretensiones ciudadanas expresadas en

185 Álvar García de Santa María, Le parti inedite..., p. 14; Álvar García de SAnTa María, Crónica..., p. 16.

${ }^{186}$ Así habría ocurrido cuando llegaron embajadores granadinos a la corte castellana en 1408. Fernán Pérez de GuzMÁn, Crónica..., año 2, cap. X, p. 308.

${ }^{187}$ Fernán Pérez de Guzmán, Crónica..., año 2, cap. V, p. 306.

${ }^{188}$ Me refiero a la concesión al infante de los cuarenta y cinco millones de maravedíes, que se habían recogido para la guerra contra el reino de Granada. Fernán PÉREZ dE GuZMÁn, Crónica ..., año 6, cap. VI, p. 344.

189 Fernán Pérez de Guzmán, Crónica ..., año 13, caps. I-II, pp. 377-378.

190 Álvar García de Santa María, Crónica..., (1891), pp. 130-131; Fernán Pérez de Guzmán, Crónica..., año 14, cap. XVII, p. 387. Sobre este personaje véase la biografía de José Manuel NiETo SORIA, Un crimen....

191 A.M.M., Cartulario Real 1411-1429, fols. 60r-v y 75r-v. Fernán Pérez DE GuZmán, Crónica..., año 12, cap. VIII, p. 376. 
las Cortes. A las Cortes se las ha considerado como un apéndice del Consejo ${ }^{192}$, y de éste se ha dicho que no sería una permanente de aquellas ${ }^{193}$. El Consejo pudo limitar, a través de su asistencia al monarca, ciertas demandas de los procuradores de las ciudades. Así parece que ocurrió con algunas de sus peticiones, como las números quince y dieciocho, en las Cortes de 1419. En ambos casos se da una respuesta esquiva, poco comprometedora, que desempeña una función idéntica a una negativa, y en la que se habla de futuro y de tener en cuenta el interés regio ${ }^{194}$. La soberanía real, con su recurso al Consejo, en determinadas cuestiones, también contribuyó a esa decadencia de las Cortes, y lo que también es evidente es que "ninguna decisión política de trascendencia podía tomarse sin el concurso de la Iglesia y de la alta nobleza" ${ }^{195}$.

\section{LA COMPOSICIÓN DEL CONSEJO REAL Y SUS LUGARES DE REUNIÓN}

Al margen de la elección, idoneidad, o las circunstancias en que los consejeros fueron nombrados, ya tratadas por otros autores, pretendo extraer unas conclusiones generales de cada grupo, tratar de ver su mantenimiento en este órgano, los posibles casos de transmisión familiar, así como la influencia que pudieron tener.

\subsection{NOBLES, ECLESIÁSTICOS Y LETRADOS}

Los integrantes de la nobleza que pertenecieron al Consejo Real durante la minoría de Juan II y que tenemos constatado, por una o varias fuentes, se elevan a treinta y cuatro, veintidos son los eclesiásticos y catorce los letrados, en total setenta consejeros196. Desde un punto de vista porcentual los nobles representan el 48,58 por ciento, los eclesiásticos el 31,42 por ciento y los letrados el 20 por ciento ${ }^{197}$. El predominio de la nobleza, es evidente. En ese grupo, quizá mejor que en los otros, se pueden diferenciar tres subgrupos, atendiendo al momento de su nombramiento y a su inclinación política posterior. De acuerdo con el primer criterio encontramos consejeros de la época de Enrique III, caso de Lorenzo Suárez de Figueroa; de los años de la regencia, por ejemplo Diego Gómez de Sandoval; y de la mayoría de edad

${ }^{192}$ Luis SuÁrez Fernández, Nobleza y Monarquía..., pp. 81-82.

193 Vicente Ángel Álvarez Palenzuela, "La Corona...”, p. 91.

${ }^{194}$ Cortes..., vol. III, (1866), (1419, pet. 15 y 18), pp. 18-19 y 20-21, respectivamente.

${ }^{195}$ Salustiano de Dios, El Consejo Real..., p. 119.

${ }^{196}$ El número quizá se podría haber incrementado, sobre todo entre los nobles, pero he preferido ser cauto y no citar a personas a las que no se alude directamente como consejeros, como pueden ser Diego Fernández de Córdoba, mariscal y señor de Baena, o Gómez Carrillo, alcalde mayor de los hijosdalgo.

${ }^{197}$ La estructura del Consejo es el reflejo de un compromiso oscilante entre la representación estamental y la pura profesionalización, como ha observado con carácter general para la Baja Edad Media castellana José María Monsalvo Antón, "Poder político y aparatos de Estado en la Castilla bajomedieval. Consideraciones sobre su problemática”, Studia Historica. Historia Medieval, IV (1986), p. 146. 
del monarca como Álvaro de Luna. Si atendemos a su inclinación política a partir de 1419-1420 encontramos que GARCIA Fernández Manrique era partidario del infante don Enrique, que su hermano, el infante don Juan, contaba con fieles como Pedro de Stúñiga, o que Juan Hurtado de Mendoza apoyaba al monarca. La única homogeneidad del grupo es la que le proporciona su condición, pero más allá se pueden encontrar diferencias en cuanto a su procedencia, por lo que hay representantes de la denominada nobleza de servicio, Ruy López Dávalos, de antiguos linajes nobiliarios castellanos, los Ayala o los Manrique, o de otros reinos peninsulares, Stúñiga, Arellano, Pimentel, por no hacer más extensiva la relación. También hay diferencias económicas, por ejemplo en cuanto a ingresos y al origen de éstos, de lo que se podía derivar una mayor o menor independencia respecto al poder regio.

Los eclesiásticos propiamente dichos, dejando al margen que pudieran serlo también algunos letrados, representaban a quince diócesis y eran el segundo grupo más importante en el Consejo Real ${ }^{198}$. Encontramos entre ellos a los arzobispos de Santiago, Toledo y Sevilla, a un grupo de obispos, casi todos ellos de sedes de la mitad Norte peninsular y uno sólo de la mitad Sur, a tres arcedianos, a un deán y a un religioso, fray Fernando de Illescas. La formación académica de cada uno de ellos era muy diferente. En efecto, podemos encontrar desde doctores como Pablo de Santa María, obispo de Cartagena, graduado en la Universidad de París, Vicente Arías de Balboa, obispo de Plasencia, o Diego Martínez, arcediano de Niebla, hasta otros prelados de los que ignoramos su nivel de instrución. Pero, sin duda, el que alcanzó mayor importancia en la minoría de Juan II fue don Sancho de Rojas, obispo de Palencia y, a partir de 1415, arzobispo de Toledo. Las percepciones económicas de cada uno de ellos serían un elemento diferenciador, a pesar de lo que pudieran recibir de la Hacienda regia por su cargo de consejeros ${ }^{199}$.

Nobles y eclesiásticos desempeñarían, con toda cautela, la presidencia del Consejo $^{200}$. ¿Se puede denominar presidente al infante don Fernando, al que su hermano, en las Ordenanzas de 1406, mandaba hacer relación si existían distintas partes enfrentadas y no se podía llegar a un acuerdo ${ }^{201}$ Es complicado inclinarse a favor o en contra, por un lado, porque quienes lo ejercieron antes y después de esta fecha fueron eclesiásticos ${ }^{202}$, aunque cabe preguntarse ¿qué objeto tenía nombrar un sustituto, el

${ }^{198} \mathrm{Su}$ presencia en el gobierno para el período anterior al aquí tratado la ha estudiado José SÁnCHEZ Herrero, "Los obispos castellanos y su participación en el gobierno de Castilla, 1350-1406", Realidad e imágenes del poder. España a fnes de la Edad Media, (Adeline Rucquoi, coord.), Valladolid, 1988, pp. 85-113.

${ }^{199}$ Enrique III dispone en su testamento lo siguiente: "Por quanto los religiosos de mi Consejo que conmigo andan yo les mandaba andar conmigo e les mandaua dar sus mantenimientos mando e ordeno que les sea dado para sus mantenimientos de aquí adelante, aquello que ordenaren los dichos tutores del dicho Prínçipe mi hijo". Álvar García de Santa María, Le parti inedite..., p. 34, especialmente; Álvar García de Santa María, Crónica..., p. 39. El texto procede de esta última edición.

200 Sobre este aspecto véase Salustiano de Dios, El Consejo Real..., pp. 86-87, especialmente.

${ }^{201}$ Real Biblioteca de El Escorial. Mss. castellanos, Z II. 7, fols. 3b-8b, publicado por Francisco Martínez Marina, Teoría..., vol. III, no XXIV, pp. 1292-1299; por Salustiano de Dios, "Ordenanzas...", no V, pp. 281-286, y por el mismo en Fuentes..., n ${ }^{\circ}$ V, pp. 21-27.

${ }^{202}$ Mariano Alcocer Martínez, "Consejo Real de Castilla”, Revista Histórica, 5 (1925), p. 35, señala que en 1402 el presidente era don Diego de Anaya Maldonado y en 1406 don Juan, obispo de Sigüenza. 
obispo de Cartagena, en caso de ausencia del infante? También plantean dudas las afirmaciones de que el arzobispo de Toledo, don Pedro de Luna, era presidente del Consejo en $1410^{203}$, la misma fecha en la que encontramos otro testimonio en el que se señala que en la campaña de 1410 el infante don Fernando dejó "por cabeza del consejo al arzobispo de Santiago don Lope de Mendoza" ${ }^{204}$, o ¿era del que lo acompañaba?

Los letrados no representarían ni la quinta parte del total de los consejeros contabilizados. Una característica general a casi todos ellos es su condición de doctores que, aunque no se expresa, sería en Leyes. Es decir, que era condición sine qua non para pertenecer a esta institución ${ }^{205}$.

Respecto a la presencia de los consejeros en la documentación a lo largo del período estudiado sólo Ruy López Dávalos y el almirante Alfonso Enríquez, aparecen citados a lo largo de siete años, comprendidos entre 1407 y 1420 . Seis veces aparece García Fernández Manrique, cinco el infante don Enrique de Aragón y Pedro Manrique, cuatro veces Diego López de Stúñiga y Juan Fernández de Velasco, y el resto, el setenta y cinco por ciento, tres veces y menos. Entre los eclesiásticos el más citado es Sancho de Rojas, que aparece mencionado ocho años, entre 1407 y 1419, le siguen don Gutierre Gomez de Toledo, en cinco y el arcediano de Almazán en tres, el resto, el ochenta y cinco por ciento, una y dos veces. Los letrados más citados son el doctor Pedro Sánchez de Castillo, en ocho años entre 1407 y 1420, el doctor Pedro Yáñez, en seis, el doctor Juan Rodríguez de Salamanca, en cinco, en cuatro el doctor Juan González de Acevedo y el resto, el sesenta y nueve por ciento, en tres y menos.

¿Qué conclusiones pueden sacarse de ello? En primer lugar, y dejando al margen que hay nombres de consejeros que por distintas razones no aparecen citados, estaría fuera de toda duda la continuidad de otros, sobre todo, los que figuran al comienzo y al final de la minoría, por citar dos casos, el mariscal Pedro Garcia y Pedro Ponce de León. En segundo término, las menores referencias, sobre todo a algunos de los miembros pertenecientes a la nobleza, pueden deberse a su nombramiento tardío como ocurrió con Pedro Fernández de Velasco y con Álvaro de Luna, a su vuelta al reino tras una temporada en el extranjero, caso del infante don Juan de Aragón, o a su presencia en el Consejo previo a las campañas granadinas, caso de Carlos de Arellano. En tercer término, un mayor número de referencias presupone una mayor cercanía y permanencia en el entorno de la corte, aunque en realidad tampoco tuviera que ser necesariamente así. Esto plantearía el problema de determinar la mayor o menor influencia que pudieron tener que, dejando al margen la de los regentes o la que pusieron en práctica los infantes de Aragón, sólo es evidente en el

${ }^{203}$ Así se señala en B.N., Col. Burriel, Mss. 13236 y R.A.H., SAlazar y CAStro, N-5, fols. 1r-43r, publicado por Yolanda Guerrero Navarrete, Proceso y sentencia ..., pp. 50-121. Óscar Villarroel GonzÁlez, Las relaciones..., p. 59, plantea la posibilidad, señalando la falta de datos sobre ello, de que su sucesor, don Sancho de Rojas fuera presidente del Consejo, basándose en su control del gobierno del reino.

${ }^{204}$ Luis PanZÁn, Recordanzas..., p. 40.

${ }^{205}$ Sobre este grupo social véase José Antonio Maravall CAsesnoves, "Los "Hombres de saber" o letrados y la formación de su conciencia estamental", EstuDıos de historia del pensamiento español. Edad Media, Madrid, 2001, 4a . ed., p. 314 y ss, en especial. 
caso de Sancho de Rojas, tanto en su persona como a través de terceros, de los que puede ser buen ejemplo el de sus sobrinos, Diego Gómez de Sandoval y el mariscal Pedro GarCIA de Herrera, también pertenecientes al Consejo Real. La pertenencia al Consejo Real también es indicativa del nivel alcanzado por el noble y además que es capaz de transmitirlo a su heredero, como ocurrió con Diego López de Stúñiga y con Juan Fernández de Velasco, de quienes lo heredaron sus hijos Pedro de Stúñiga y Pedro Fernández de Velasco, respectivamente. Aunque el mantenimiento del cargo de consejero en la misma familia dependió en ocasiones de la inclinación política del progenitor en un momento dado. Este debió ser el caso del maestre de Santiago, don Lorenzo Suárez de Figueroa, más favorable a la reina doña Catalina que al infante don Fernando, cuyo heredero, Gome Suárez de Figueroa, no recibió el nombramiento de consejero a la muerte de su padre en 1409 , sino en 1421 y por otras razones ${ }^{206}$.

Uno de los rasgos que caracteriza a buena parte de los consejeros fue su polivalencia, que podemos concretar en tres ámbitos: administrativo, militar y diplomático. En el primero pueden incluirse los nombramientos de los doctores Juan Alfonso de Toro como corregidor de Sevilla, por medio año ${ }^{207}$, y el de Juan Rodríguez [de Salamanca] de Burgos ${ }^{208}$. En el segundo hay que decir que la práctica totalidad de los nobles del Consejo Real tomaron parte en las campañas militares contra el reino nazarí durante la minoría de Juan II, al igual que algunos integrantes del estado eclesiástico, como el obispo de Palencia, o el arzobispo de Santiago. De carácter diplomático fue la asistencia del Consejo al infante don Fernando en sus pretensiones al trono de Aragón. En efecto, el Consejo envió una embajada compuesta por tres de sus miembros, don Sancho de Rojas, a la sazón obispo de Palencia, Diego López de Stúñiga y el doctor Pedro Sánchez del Castilloo ${ }^{209}$. En 1412 la embajada tuvo a los mismos integrantes, a los que se añadió esta vez otro miembro del Consejo, el almirante Alfonso Enríquez. Sin embargo, Pedro Sánchez del Castillo desempeñaría después una función diplomático-jurídica al estar presente en la resolución de Caspe $^{210}$. El Consejo también envió a dos de sus miembros, Diego López de Stúñiga y Diego Gómez de Sandoval, a Navarra para mediar ante su corte tras la huida de don Fadrique, refugiado en ese reino ${ }^{211}$. A Portugal ante la preocupación por el destino de la flota que armaba ese reino, donde destacó al obispo de Mondoñedo, Álvaro Núñez de Isorna y a Dia Sánchez de Benavides, caudillo del obispado de Jaén ${ }^{212}$. O tras el hecho de Tordesillas, en julio de 1420, cuando el infante don Enrique recurrió a los

206 A.D.M., Archivo Histórico, leg. 243, nº 59, Joaquín GonzÁlez Moreno, Catálogo del Archivo General de la Casa Ducal de Medinaceli, vol. III, Sevilla, 1973, p. 118. Fernando Mazo Romero, El Condado de Feria (1394-1505). Contribución al pr oceso señorializador en Extr emadura durante la Baja Edad Media, Badajoz, 1980, pp. 154-155.

${ }^{207}$ Francisco Collantes de Terán Delorme, Archivo Municipal..., vol. II, no 1, pp. 31-32. Sin especificar el tiempo véase Fernán Pérez de Guzmán, Crónica..., año 12, cap. V, p. 375.

208 A.M.Bu., Actas del Concejo, (1411 marzo 27), fol. 8r-v.

${ }^{209}$ Fernán Pérez de Guzmán, Crónica ..., año 5, cap. IX, p. 336.

210 Jerónimo Zurita, Anales..., Lib. XI, cap. LXXXIII, p. 251.

${ }^{211}$ Luis Panzán, Recordanzas..., pp. 57-58.

${ }^{212}$ Monumenta Henricina, vol. II, $\mathrm{n}^{\circ}$ 40, pp. 103-106, que lo toma de Gomes Eanes de Zurara, Crónica ..., cap. XXXII, pp. 125-127. Del primero ya he señalado que pertenecía al Consejo, sin embargo, de Sánchez de Benavides no he encontrado ninguna referencia que así lo señale. 
oficios diplomáticos de don Gutierre Gómez de Toledo, que era uno de sus partidarios y pertenecía al Consejo, para que presentase sus reivindicaciones ante la corte del papa Martín $\mathrm{V}^{213}$.

Estas y otras ocupaciones, como la condición de oidor de muchos de ellos ${ }^{214}$, añadidas a las propias de su cargo pudieron provocar en los consejeros una gran carga de trabajo, por lo que en alguna ocasión, como ante un requerimiento del concejo de Cuenca, el propio rey les contesta que "los de mi consejo están ocupados en otros muchos negoçios que cumplen mucho a mi serviçio que de present non se pueden veer pero yo las mandaré veer e proveeré sobrello como la mi merçet fuere e cumpliere a mi serviçio" ${ }^{215}$.

\section{Miembros del Consejo Real durante la minoría de Juan I}

\begin{tabular}{lll} 
Nobles & Eclesiásticos & Letrados \\
\hline Alfonso Enríquez & Álvar Núñez de Isorna & Diego Rodríguez \\
Alfonso Tenorio & Arcediano de Almazán & Fernando González de Ávila \\
Álvaro de Luna & Deán de Santiago & Fortún Velázquez de Cuéllar \\
Carlos de Arellano & Diego de Anaya Maldonado & Juan Alfonso de Coria \\
Conde de Benavente & Diego Gómez de Fuensalida & Juan Alfonso de Toro \\
Diego Fernández de Córdoba & Diego Martínez, arcd. de Niebla & Juan González de Acevedo \\
Diego Fernández de Quiñones & Fray Fernando de Illescas & Juan González de Villegas \\
Diego Gómez de Sandoval & Gonzalo Rodríguez de Neira & Juan Martínez, cller. sello puridad \\
Diego López de Stúñiga & Gutierre Gómez de Toledo & Juan Pérez de Villegas \\
Enrique de Guzmán & Juan Cabeza de Vaca & Juan Rodríguez de Salamanca \\
Enrique Manuel & Juan de Guzmán & Juan Sánchez de Suazo \\
Enrique, maestre de Calatrava & Juan de Illescas & Pedro López \\
Fadrique de Trastamara & Juan Enríquez & Pedro Sánchez del Castillo \\
Fernán Pérez de Ayala & Juan González de Villegas & Pedro Yáñez
\end{tabular}

213 Álvar García de Santa María, Crónica..., (1891), pp. 134-135; Fernán Pérez de Guzmán, Crónica..., año 14, cap. XX, p. 388.

${ }^{214}$ Valgán como ejemplo los doctores Juan Rodríguez de Salamanca, Juan Sánchez de Suazo, Juan Fernández de Toro, Fortún Velázquez de Cuéllar, Pedro Yáñez o Gutierre Gómez de Toledo.

${ }_{215}$ A.M.C., Actas del Concejo (1418 septiembre 16), fols. 24v-25r. 


\begin{tabular}{|c|c|c|}
\hline Nobles & Eclesiásticos & Letrados \\
\hline Fernando Alfonso de Robles & Juan Vázquez de Cepeda & \\
\hline GARCIA Fernández Manrique & Juan, obispo de Sigüenza & \\
\hline Gómez Manrique & Lope de Mendoza & \\
\hline Infante don Enrique & Pablo de Santa María & \\
\hline Infante don Juan & Pedro de Luna & \\
\hline Infante don Pedro & Pedro, obispo de Orense & \\
\hline Juan Fernández de Velasco & Sancho de Rojas & \\
\hline Juan Hernández Pacheco & Vicente Arias de Balboa & \\
\hline \multicolumn{3}{|l|}{ Juan Hurtado de Mendoza } \\
\hline \multicolumn{3}{|l|}{ Lorenzo Suárez de Figueroa } \\
\hline \multicolumn{3}{|l|}{ Martín Fernández de Córdoba } \\
\hline \multicolumn{3}{|l|}{ Pedro de Stúñiga } \\
\hline \multicolumn{3}{|l|}{ Pedro de Velasco } \\
\hline \multicolumn{3}{|l|}{ Pedro Garcia de Herrera } \\
\hline \multicolumn{3}{|l|}{ Pedro López de Ayala } \\
\hline \multicolumn{3}{|l|}{ Pedro Manrique } \\
\hline \multicolumn{3}{|l|}{ Pedro Ponce de León } \\
\hline \multicolumn{3}{|l|}{ Per Afán de Ribera } \\
\hline \multicolumn{3}{|l|}{ Prior de la Orden de San Juan } \\
\hline Ruy López Dávalos & & \\
\hline
\end{tabular}

\subsection{LAS MUJERES}

¿Cuál fue el papel de las mujeres en el Consejo? La presencia de una mujer en el Consejo Real era un hecho excepcional, en una institución, como tantas otras dominadas por los hombres. La única mujer que tuvo acceso, aunque no en calidad de consejera $^{216}$, fue la reina doña Catalina. Sin embargo, aunque la reina tomase parte en las resoluciones del Consejo e influyese en alguna de sus decisiones de las que se ha dado cuenta, quizá lo más llamativo sea el papel que se atribuye a ciertas mujeres de su entorno, en concreto a doña Leonor López de Córdoba. Según Panzán, doña Leonor pudo acompañar a la reina en algún Consejo ${ }^{217}$, si eso fue así se estaba vulnerando la Ordenanza de Segovia de 1406, que incluso disponía la salida del lugar donde se celebraba para los referendarios si se trataban asuntos importantes o secretos y pro-

${ }^{216}$ En el caso de Francia se señala, como hecho excepciónal, la existencia de dos consejeras, entre un total de doscientos ochenta y dos consejeros estudiados. Para su conocimiento remitimos al trabajo de Pierre-Roger Gaussin, "Les conseillers de Charles VII (1418-1461). Essai de politogie historique", Francia, 10 (1982), p. 93.

${ }^{217}$ Luis PANZÁn, Recordanzas..., pp. 52 y 64. Quizá quede más claro en el manuscrito 26. II. 13, del Instituto Valencia de Don Juan que he utilizado y que es en el que se basa el libro. 
hibía la entrada en él sin licencia ${ }^{218}$. En cualquier caso, no sería más que una muestra del enorme poder que ejercía sobre la soberana. Sin embargo, lo más destacable de la actuación de doña Leonor habría sido el cuestionamiento de las decisiones del Consejo $^{219}$, que implicaba el enfrentamiento entre ambos regentes y que a medio plazo provocó su salida de la corte. A pesar de ello, la influencia de doña Leonor sobre el Consejo y sus decisiones traspasó el período de su estancia en la corte. Por iniciativa suya se encumbrará a algún personaje que años después acabó formando parte del Consejo Real, como ocurrió con Fernando Alfonso de Robles, que junto con Inés de Torres, también puesta por la privada, a la altura de 1416 "hacían todos los negocios como les placía, sin acuerdo de los Grandes ni de los otros del Consejo"220.

\subsection{LOS AUXILIARES}

Las tareas auxiliares del Consejo Real fueron competencia, entre otros, de los porteros, escribanos y refrendarios.

Los porteros del rey tenían encomendadas varias funciones, una de ellas sería exigir la devolución de una fortaleza, como ocurrió con el que llevaba la carta real enviado por el Consejo a Tarifa ${ }^{221}$. Sin embargo, la principal era la guarda de las puertas del lugar donde se celebraba el Consejo. En este cometido es posible que estuviesen auxiliados por los ballesteros de maza, de los cuales, según la Ordenanza de Segovia de 1406, debería haber dos en la puerta del lugar donde se celebraba. Nos consta el celo con el que alguno de ellos se tomaba su trabajo impidiendo presentar ante los del Consejo un testimonio de emplazamiento, "por quanto la Reyna estava ocupada de çiertos negoçios" "222. Por el contrario, la probidad de otros podría ser más cuestionable, toda vez que se conoce la remuneración que algún concejo les hacía de forma generosa "por el trabajo que tomaban dando puerta cada vez que lo habían menester, a los oficiales del concejo" ${ }^{223}$, lo que nos lleva a pensar en la venalidad como práctica.

Por su parte, los escribanos tenían encomendado poner por escrito lo tratado en el Consejo. La nómina de los que pertenecían al Consejo Real sería de dieciocho, repartidos en tres grupos de seis $^{224}$. Su número en las reuniones variaba en razón de

${ }^{218}$ Real Biblioteca de El Escorial. Mss. castellanos, Z II. 7, fols. 3b-8b, publicado por Francisco Martínez Marina, Teoría..., vol. III, no XXIV, pp. 1292-1299; por Salustiano de Dios, "Ordenanzas...", n ${ }^{\circ} \mathrm{V}$, pp. 281-286, y por el mismo en Fuentes..., n ${ }^{\circ} \mathrm{V}$, pp. 21-27.

219 Fernán Pérez de Guzmán, Crónica..., año 1, cap. II, p. 278; Álvar García de Santa María, Crónica..., pp. 56-58.

${ }^{220}$ Fernán Pérez de Guzmán, Crónica..., año 10, cap. X, p. 372. Sobre Fernán AlFonso de Robles véase el artículo de Máximo Diago Hernando, "El contador Fernán Alfonso de Robles. Nuevos datos para su biografía", Cuadernos de Historia de España, LXXV (1998-1999), pp. 117-133.

${ }^{221}$ A.D.A., carp. 77, $n^{\circ}$ 10; R.A.H., Col. Salazar y Castro, M-50, fols. 13r-22v.

222 A.H.N., Clero, leg. 5342.

${ }^{223}$ Francisco Collantes de Terán Delorme, Archivo Municipal..., vol. I, no $23, \mathrm{n}^{\circ} 54 \mathrm{y} \mathrm{n}^{\circ} 56, \mathrm{n}^{\circ} 98$ y n ${ }^{\mathrm{o}} 101$, pp. 208-209, 214-215 y 223 . Vol. II, no 16 , p. 35, respectivamente.

${ }^{224}$ Francisco de Paula CaÑas Gálvez, La burocracia regia durante el reinado de Juan II de Castilla: Estudio pr osopográf co e itinerario, Tesis doctoral, Universidad Complutense, vol. I, Madrid, 2005, p. 237. 
la mayor o menor importancia de los acuerdos que se tratasen, y oscilaría entre uno y cuatro, según la Ordenanza de Segovia de 1406. En esta misma disposición se contiene la obligación de avisar al monarca cuando librase algo el Consejo, para "que lo escribiese en un memorial el escribano cuyo cometido era ese libramiento" ${ }^{225}$. Sin embargo, su ámbito de actuación no se limitó estrictamente al Consejo, pues alguno también sirvió como escribano de cámara y desempeñó otras funciones. Buen ejemplo de ello es Gutierre Díaz, escribano de cámara del rey, que alternó el libramiento de misivas del Consejo con los documentos firmados por los tutores, entre julio de 1408 y febrero de $1414^{226}$. Este burócrata fue enviado a la corte granadina para protestar ante su rey por la toma y combate de Priego, estando asentadas treguas ${ }^{227}$. También estuvo presente en Granada para la ratificación de las nuevas, que se otorgaron en 1408 hasta finales del mes de marzo del año siguiente ${ }^{228}$. Casos similares al suyo los encontramos en Ruy López, en Diego Fernández de Vadillo o en Sancho Romero ${ }^{229}$.

La cercanía de estos escribanos al monarca o la protección de algún importante personaje de la corte, al margen de la confianza o de su valía, están destrás del ascenso de alguno de ellos. Los dos ejemplos más claros durante la minoría de Juan II nos los ofrecen Fernando Alfonso de Robles y Diego Rodríguez de Valladolid, que pasaron de ser escribanos a miembros del Consejo Real ${ }^{230}$. Sin alcanzar esta dignidad nos ha quedado constancia escrita de la vivencia de alguno de ellos, como ocurre con Luis Panzán, que se titula escribano del Consejo ${ }^{231} \mathrm{y}$ autor de una obra ya citada.

Los escribanos de cámara, residentes en el Consejo Real, percibían 8.400 maravedíes anuales, a lo que hay que sumar el privilegio de cuatro excusados ${ }^{232}$.

Los refrendarios o referendarios se encargaban del refrendo de los documentos, sin embargo, al margen de ello las Ordenanzas de Segovia de 1406 les encomendaban organizar los asuntos a tratar por el Consejo, tomar las peticiones que llegasen de todo el reino, y hacer de ellas relación al Consejo, establecer el número de personas que podría permanecer en la sala del Consejo, y redactar un memorial ${ }^{233}$. Durante la minoría de Juan II habrían sido refrendarios los doctores Pedro Sánchez del Castillo, Pedro Yáñez de Ulloa -Periáñez-, Diego Rodríguez de Valladolid, Gutierre Gómez

${ }^{225}$ Real Biblioteca de El Escorial. Mss. castellanos, Z II. 7, fols. 3b-8b, publicado por Francisco Martínez Marina, Teoría..., vol. III, n XXIV, pp. 1292-1299; por Salustiano de Dios, "Ordenanzas...", no V, pp. 281-286, y por el mismo en Fuentes..., n ${ }^{\circ}$ V, pp. 21-27.

${ }^{226}$ Francisco de Paula CAÑas Gálvez, La burocracia regia..., vol. I, p. 237.

227 Álvar García de Santa María, Le parti inedite..., p. 3; Álvar García de Santa María, Crónica..., pp. 253-254.

228 Álvar García de Santa María, Crónica..., p. 258.

${ }^{229}$ Francisco de Paula Cañas Gálvez, La burocracia regia..., vol. I, p. 237.

${ }^{230}$ Francisco de Paula CAÑas Gálvez, La burocracia regia..., vol. I, p. 232. El caso del primero lo indica Fernán Pérez de Guzmán, Generaciones, Semblanzas..., p. 711. Véase también Máximo Diago Hernando, "El contador...", pp. 117-133.

${ }^{231}$ Luis PAnzÁn, Recordanzas..., p. 34.

${ }^{232}$ Francisco de Paula Cañas Gálvez, La burocracia regia..., vol. I, pp. 243-244.

${ }^{233}$ Real Biblioteca de El Escorial. Mss. castellanos, Z II. 7, fols. 3b-8b, publicado por Francisco Martínez Marina, Teoría..., vol. III, n XXIV, pp. 1292-1299; por Salustiano de Dios, "Ordenanzas...", n V, pp. 281-286, y por el mismo en Fuentes..., n ${ }^{\circ}$ V, pp. 21-27. 
de Toledo y Fernando González de Ávila ${ }^{234}$. Por citar tan sólo unos casos de los muchos en los que intervinieron, sabemos que el doctor Periáñez refrendó el testamento de Enrique III ${ }^{235}$, y que estuvo en calidad de refrendario junto a Pedro Sánchez del Castillo, en el juramento de aceptación de la tutoría del rey por los dos regentes ${ }^{236}$. El doctor Pedro Sánchez del Castillo también tomó parte en la negociación de unas treguas con Portugal en $1407^{237}$. Los refrendarios tenían asignada una ración diaria de 40 maravedíes, que suponían algo más de 14.000 anuales, a lo que hay que añadir las ayudas de costa complementarias ${ }^{238}$.

\subsection{LOS LUGARES DE REUNIÓN}

La citada Ordenanza de Segovia de 15 de septiembre de 1406 también disponía sobre el lugar de reunión del Consejo y las condiciones que debería tener. En ella se señala la cámara del rey, como lugar preferente, o en caso de imposibilidad en las cercanías de donde éste estuviese alojado. Por desgracia, crónicas y documentos son demasiado parcos a la hora de detallar los lugares de celebración del Consejo, en muchos casos podemos intuir que tuvo lugar en los alcázares de las ciudades donde estaba la corte, así habría ocurrido en Guadalajara en 1408, en Córdoba en 1410, o en Segovia en 1419. Por el contrario, conocemos que el lugar de reunión del Consejo, a comienzos del reinado de Juan II, fue en "los palacios" del obispo de Segovia ${ }^{239}$, o que durante la campaña de ese mismo año -1407-, fue en la tienda del infante don Fernando ${ }^{240}$. En 1410, tras la finalización de la campaña de Antequera, durante la estancia de don Fernando en Sevilla, cuando se trataron sus derechos al trono de Aragón, el Consejo se reunió primero en "el palacio del Caracol que es dentro del alcázar", y después en varias ocasiones en la capilla de los Reyes de la catedral de Sevilla ${ }^{241}$. Con el mismo fin lo hizo más tarde en la capilla del monasterio de los Predicadores donde residían el rey y la reina en Valladolid ${ }^{242}$. Antes de enviar tropas a Aragón se celebró el Consejo en la iglesia del castillo de Ayllón, en 1411 ${ }^{243}$, y conocida la sentencia de Caspe, a finales de junio de 1412, se leyó al Consejo que acompañaba a don Fernando en Cuenca en las casas del obispo ${ }^{244}$. El rey acordó en

${ }^{234}$ Francisco de Paula CAÑAs Gálvez, La burocracia regia..., vol. I, p. 71. El citado en último lugar en vol. II, p. 63.

${ }^{235}$ Álvar García de Santa María, Le parti inedite..., p. 37; Álvar García de Santa María, Crónica..., p. 42.

${ }^{236}$ R.A.H., Col. Salazar y Castro, M-92, fols. 128r-131v. Álvar García de Santa María, Le parti inedite..., p. 40; Álvar García de Santa María, Crónica..., p. 46.

${ }^{237}$ Álvar García de Santa María, Le parti inedite..., p. 49; Álvar García de Santa María, Crónica..., p. 55.

${ }^{238}$ Francisco de Paula Cañas Gálvez, La burocracia regia..., vol. I, p. 83.

239 Álvar García de Santa María, Crónica..., p. 57. En la página siguiente también se los denomina "posadas del obispo de Segouia".

${ }^{240}$ Fernán Pérez de Guzmán, Crónica..., año 1, cap. L, p. 298.

${ }^{241}$ Las dos referencias en Luis Panzán, Recordanzas..., pp. 43 y 45, respectivamente.

${ }^{242}$ Luis PANZÁn, Recordanzas..., p. 52 y 58.

${ }^{243}$ Luis PanzÁn, Recordanzas..., p. 64.

${ }^{244}$ Luis Panzán, Recordanzas..., p. 100. 
Madrid, en 1419, que el Consejo se reuniese donde estaba alojado el condestable, por la enfermedad de la gota que le aquejaba a éste ${ }^{245}$. El Consejo también se celebró en el palacio nuevo de Tordesillas, tras los acontecimientos del 14 de julio de $1420^{246}, \mathrm{y}$ en los castillos de Montalbán, durante el cerco al rey ${ }^{247}$, y de Villalba tras su liberación, en diciembre de ese mismo año ${ }^{248}$.

\section{CONCLUSIÓN}

La trayectoria del Consejo Real durante la minoría de Juan II corrió pareja a los cambios en el gobierno de Castilla. Por ello, pueden diferenciarse tres momentos, el primero que abarcaría hasta la muerte del rey Fernando I de Aragón, aunque se puede extender con algunos matices hasta la desparición de doña Catalina, el segundo, desde entonces hasta mayo de 1419 , y el tercero desde esa fecha hasta los acontecimientos de Tordesillas en 1420. En el Consejo Real se dirimen las diferencias, se manifiesta el poder de que disponen, o los apoyos con los que cuentan, los regentes y los nobles que más tarde se hicieron con el gobierno. Unos y otros lo utilizaron para ganar adeptos, creando de nuevo el problema del elevado número de consejeros, que no hizo más que agravarse durante esta etapa. El Consejo fue un útil instrumento de gobierno, por lo que se ocupó de asuntos muy diversos, sobre todo políticos, hacendísticos y judiciales. Refleja del predominio de las elites sobre el estamento ciudadano, más evidente si cabe desde 1416. Es lugar de promoción de "Hombres de saber", o letrados, que lo integran, y de una incipiente burocracia. También es una muestra más del eje del poder trazado por la itinerante corte castellana.

${ }^{245}$ Fernán Pérez de Guzmán, Crónica ..., año 13, cap. IV, p. 378.

${ }^{246}$ Fernán Pérez de Guzmán, Crónica ..., año 14, caps. II y III, pp. 380-381.

247 Álvar García de Santa María, Crónica..., (1891), p. 187.

248 Álvar García de Santa María, Crónica..., (1891), p. 192; Fernán Pérez de Guzmán, Crónica..., año 14, cap. XLVII, p. 398. 